TT

805

T29

CHM

\title{
TENERIFFE LACE WORK
}

SMITHSOMUNM

LIBRAMIES 


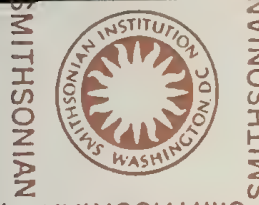

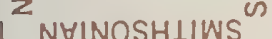

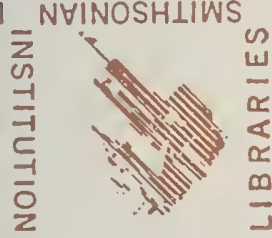

SMITHSONIAN
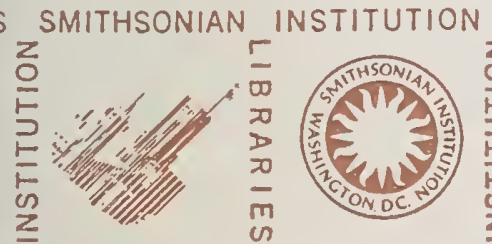

(n) 2
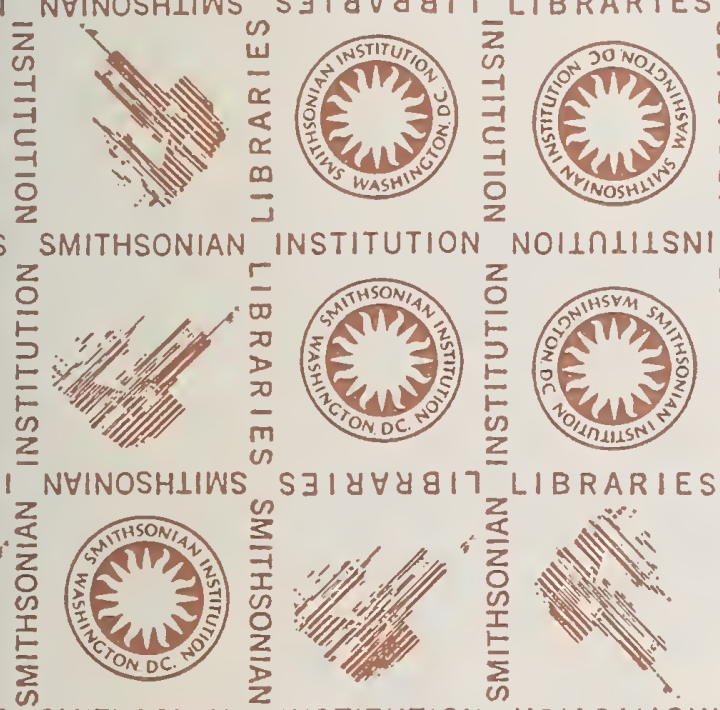

$S$ SMITHSONIAN

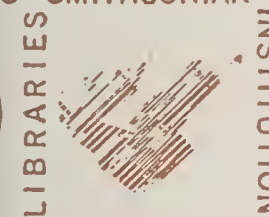

VI

VI

INSTITUTION

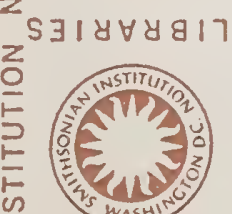

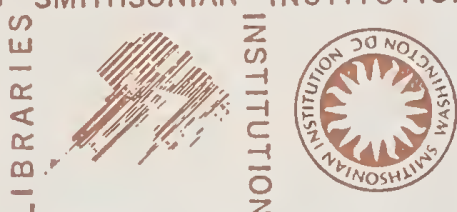

NYINOSHLIWS

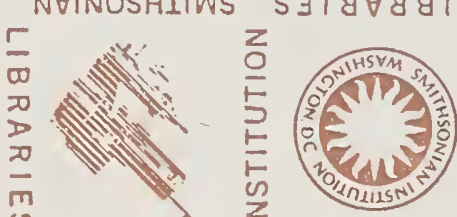

en 2. Z
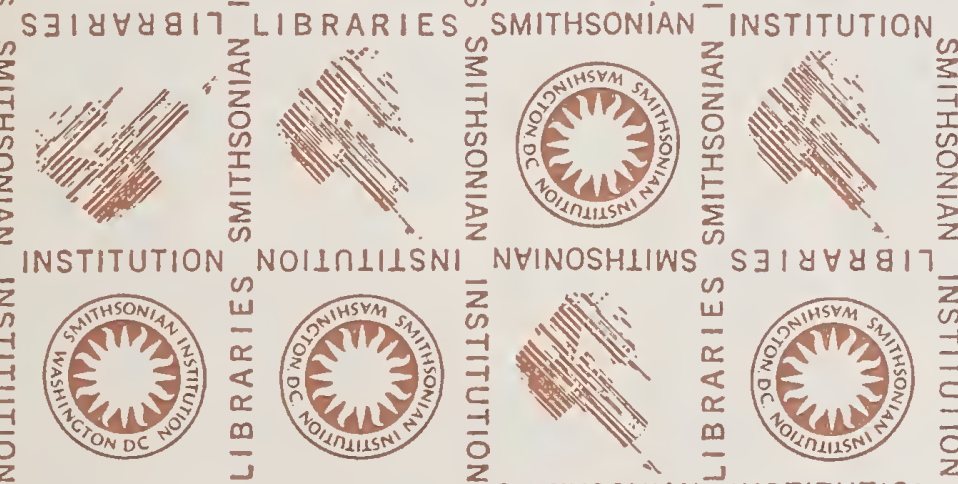

$5314 \forall 4817$

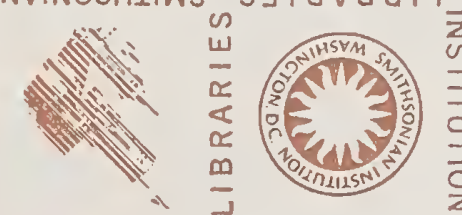

LIBRARIES SMITHSONIAN

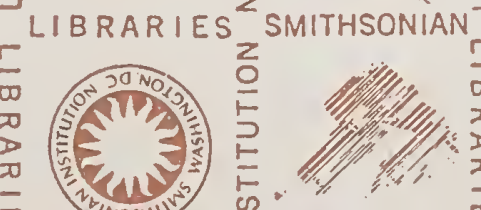

NOIIN $111 S N$
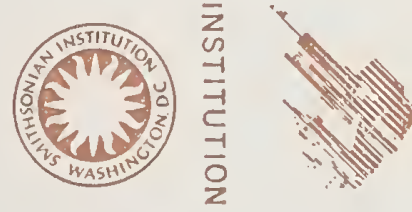

LIBRARIES SMITHSONIAN
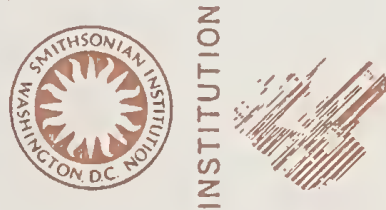

5
$\infty$
$\infty$
$\frac{1}{m}$
$m$

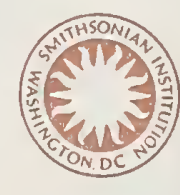

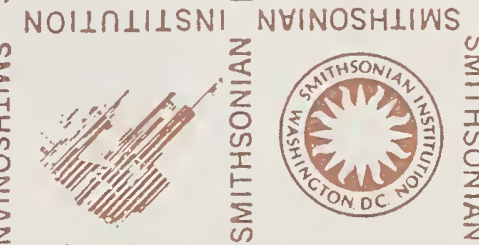

LIBRARIES" SMITHSONIAN
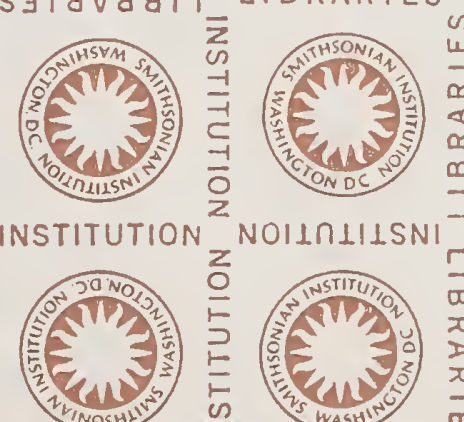

$\frac{2}{5}$

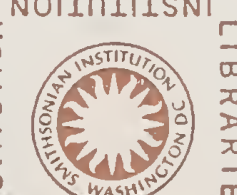

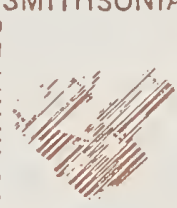

$\bar{z}$
un
-1
$\overline{-1}$
$c$
-1
$\overline{0}$
$z$

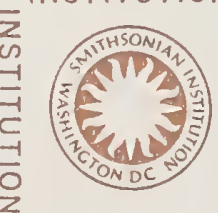

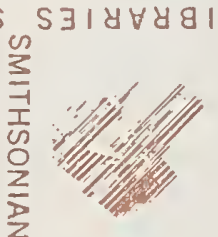

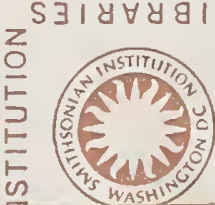


.

.

.

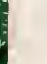




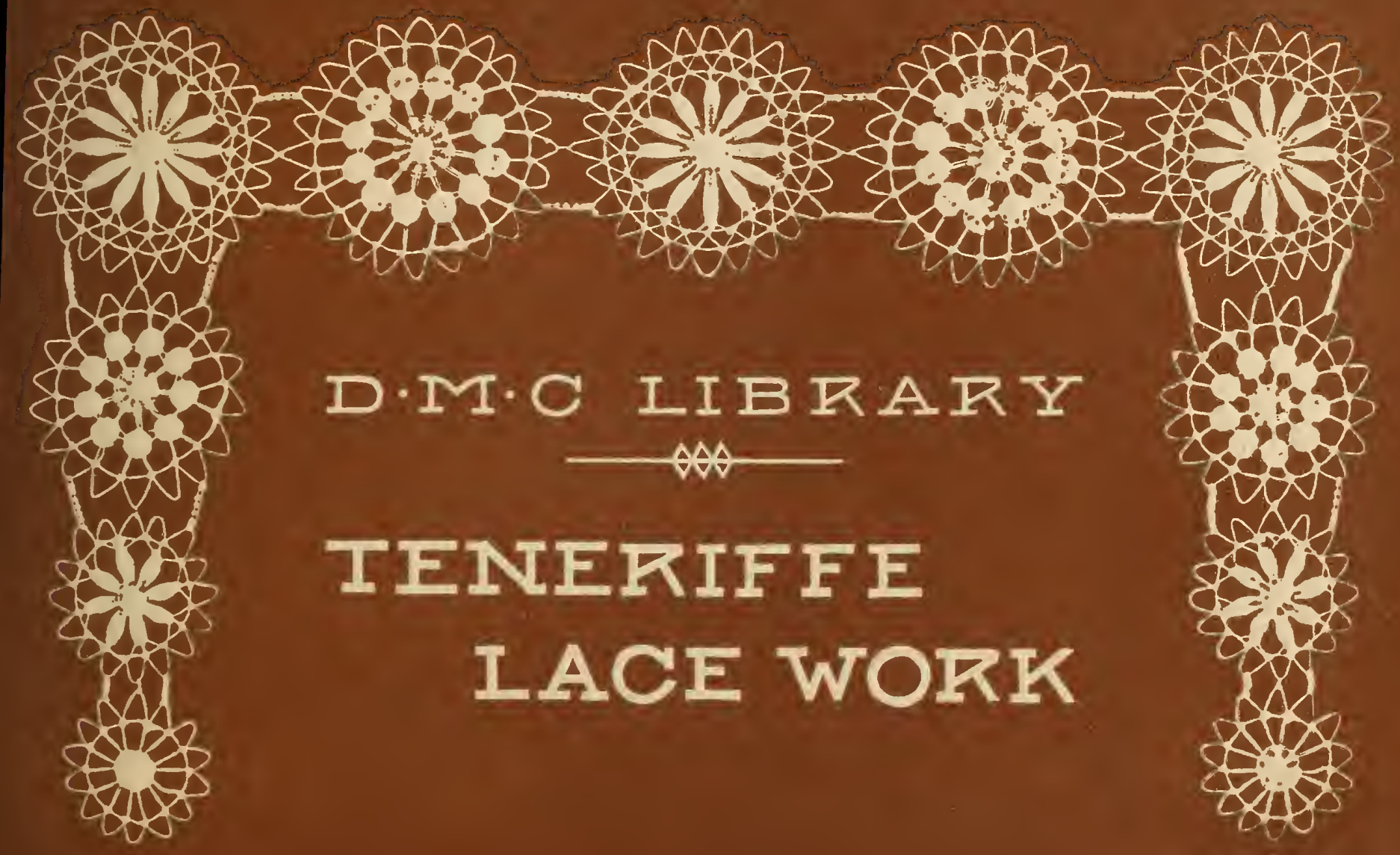




$$
D \cdot M \cdot C \quad L I B R A R Y
$$

\section{Teneriffe lace work}
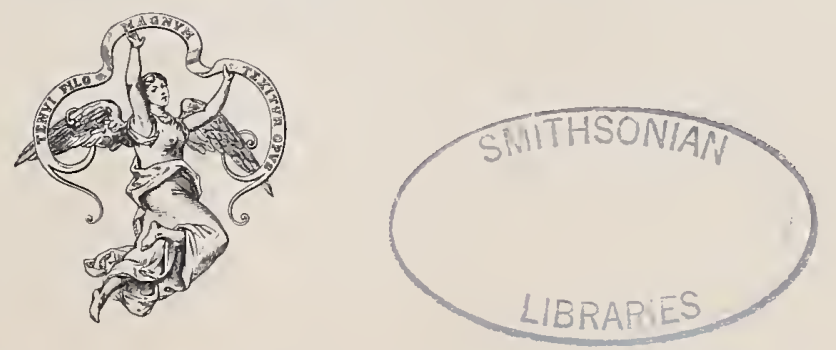

EDITIONS TH. DE DILLMONT, S. à r. 1 .

MULhouse (Frânce) 
Giptor

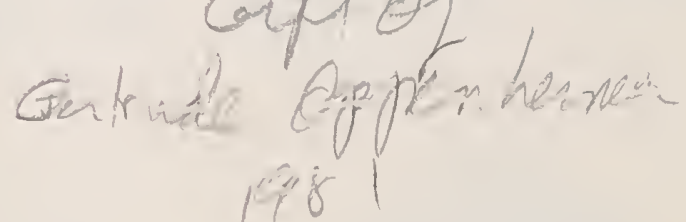




\section{Teneriffe lace work.}

Teneriffe lace is a kind of work long known in Southern and Central America under the name of Brazilian or Bolivian lace. It is an imitation of a kind of needlework practised in Spain in the xvith and xvith centuries and known as "Sols" (Sun lace).

Originally "Sol lace" was made on a linen ground and ranked as "openwork on linen". Little by little, however, a change took place in the method of working it and what we now in Europe call "Teneriffe" lace is no longer made on a linen foundation but is properly speaking a lace.

Implements. - These are of various kinds: cushions, metal or india rubber discs, \&c.

For our patterns we have used india rubber discs with small metal teeth round their edges.

Figure I represents on a reduced scale a disc of this kind, one side of which is covered with a layer of dark cloth to make it less trying for the eyes in working. The little metal teeth serve to keep the threads tightly stretched for the web.

Some discs have a similar row of teeth on the inside edge, so that a greater number of threads can be used for the web.

For insertions, braids and lace edgings, special moulds are used of a shape and size to suit the work to be done. 
Needles. - There are special needles for Teneriffe lace; they are very long, of uniform thickness and without points. They are slightly curved and flattened at the extremity to enable the threads of the web to be picked up more easily.

Materials. - These must be selected with a view to the purpose the work is intended to serve. For trimming wearing apparel for which a fine lace is required, use the finer numbers

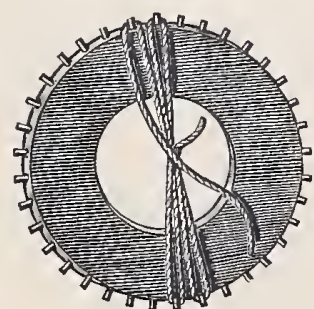

Fig. $x$.

How to stretch the web on a disc with a single row of teeth. of D.M.C Flax lace thread (Lin pour dentelles), D.MICC Cotton lace thread (Fil à dentelles) or D.M.C Alsatian thread (Fil d'Alsace) in white, cream or écru; for table or bed linen, we recommend the coarser numbers of $\mathrm{D} \cdot \mathrm{M} \cdot \mathrm{C}$ Crochet cotton, special quality (Cordonnet spécial) and D.M.C Flax thread for knitting and crochet (Lin pour tricoter et crocheter); for coloured braids use D.M.C Pearl cotton (Coton perlé) (*).

The above-named articles serve to form the stretched web and the knots that hold and fix it; where the pattern requires ornamental figures in darning stitch use a loose thread such as D.M.C Special stranded cotton (Mouliné spécia1), D·M.C Floss flax or flourishing thread (Lin floche), D·M.C Rayon for embroidery (Rayonne à broder) or D·M.C Persian silk (Soie de Perse).

Method of working. - After stretching the threads over the disc make the rows of knots that complete the web, beginning at the outside edge, then fill the centre and lastly work the different ornamental stitches.

To renew the thread, make a weaver's or reef knot, which must touch a knot of the web or be hidden under a little ornamental figure.

(*) The French names in brackets are those stamped on the labels of the $\mathrm{D} \cdot \mathrm{M} \cdot \mathrm{C}$ articles. 
How to stretch the web for the medallions (figs. I, 2, and 3). - With the thread unwound from the ball make a loop knotted at the bottom, its length equal to half the diameter of the disc to be covered, and hook it round one of the teeth. The knot of the loop will thus come just in the centre of the disc, and beside the knot there will be an end of thread

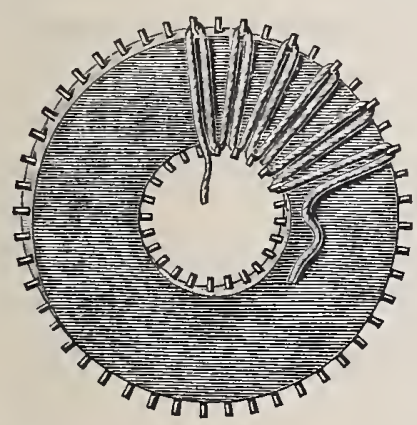

Fig. 2.

How to stretch the web on a disc with teeth on both rims. First round. which, later on, will serve for fastening off the last thread stretched.

Take the thread from the ball in the right hand and, passing it across the disc, hook it on to the opposite tooth. 'Then take it upwards again to the tooth next to the first tooth, and so on till all the teeth are occupied (fig. I), and the central space is entirely covered with threads. I astly, fasten the thread to the loose end of the first loop by a weaver's or reef knot.

Large discs, the inside rims of which are edged with teeth as well as the outside, are

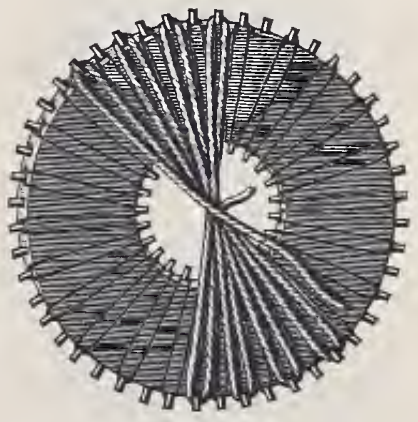

Fig. 3 .

How to stretch the web on a disc with teeth on both rims. Second round.

covered in two rounds. In the first round (fig. 2), the thread is passed zig-zag fashion alternately over one of the inner and one of the outer teeth; it always passes over the next tooth on the inside rim and the next but one on the outside; in the second round (fig. 3), the thread is stretched right across, as in the smaller discs which have no inside teeth, but passing over only those teeth that have been left free in the first round. 
How to make the web for insertions and lace. - For these the threads can be mounted in one or two rounds. In the former case, take alternately one upper and one lower tooth, always taking the next one; in the latter, take every other tooth only in the first round, and in the

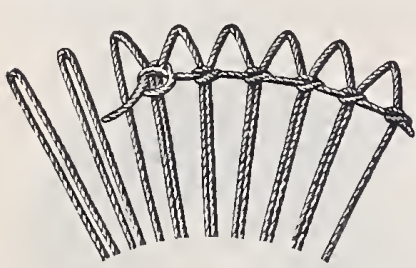

Fig. 4. Knot in twisted chain stitch.

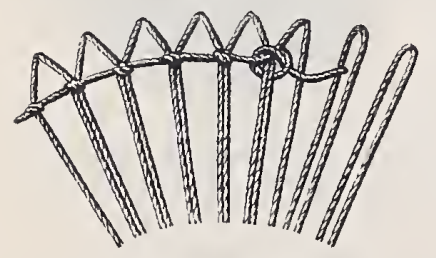

Fig. 5. Single knot. second the teeth left free in the first round. The two layers of threads, one over the other, will naturally cross each other in the centre of the mould.

How to make the knots that fix the stretched threads in place (figs. 4 and 5). - To complete the web, make several rows of knots which keep the stretched threads in place.

Each thread can be knotted separately, or two or more can be joined by one knot. The same kinds of knots are used as in drawn thread work on linen: the collecting knot formed by a small twisted chain stitch (fig. 4), and the single knot (fig. 5).

The making of the first row of knots produces at the same time the little loops of the outer edge; the succeeding rows, arranged in different ways, partly form the pattern.

When successive rows of knots are made over the same threads of the web, small square spaces are formed between these rows; by alternating the knots, that is to say dividing between them the clusters of threads produced by a preceding row, a sort of serpentine openwork design is formed; designs composed of large clusters are the result of joining together several smaller clusters of threads. 
These three ways of grouping the threads can all be used in the same piece of work, as the illustrations show.

How to ornament the centre of the medallions. - The centre of the medallion, where the stretched threads cross, is always ornamented with a small wheel. This is made in darning or ribbed stitch, whichever best suits the other parts of the design, with which it should always be in keeping.

Ornamental stitches and figures. - After making all the rows of knots and the wheel in the middle of the medallion, the preparatory work is complete. For filling the empty spaces any of the various stitches used in drawn thread work and needle-made lace can be used; very pleasing effects are produced with various rows of crossed threads finished off top and bottom by a row of small wheels or rows of darning or buttonhole stitching.

How to cross the clusters of threads (figs. 6 and 7 ). - The threads are crossed in each row just as in openwork rows; in fact all the motifs and stitches used in openwork on linen can be used for Teneriffe lace.

Fig. 6 shows in detail the simplest kind of row, formed by two

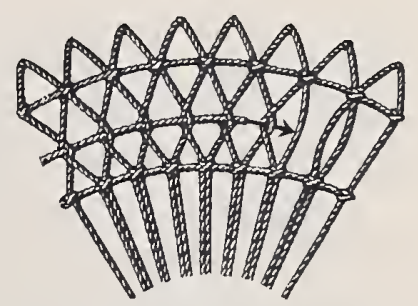

Fig. 6. Row of threads crossed once.

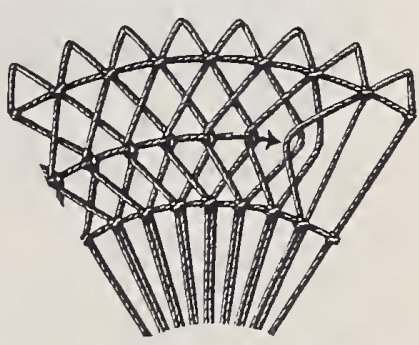

Fig. 7. Row of threads crossed twice. threads crossed once; while fig. 7 shows the working of a row where the threads are crossed twice.

How to knot the clusters of threads. - Usually the clusters of threads are made by the rows of knots which fix the web. However, the model sometimes requires that the clusters should 
form a pattern with a zig-zag line in the middle. In this case the first of the already knotted clusters must be divided and the thread twisted once or twice round half the threads of the cluster, until the first part of the next cluster is reached; then the two parts are joined, and the thread is carried on to the next part, and so on.

Wheels. - The ornamental motif most often used in this kind of work is the wheel or spider. It is worked in darning stitch, simple or alternated, or in ribbed stitch.

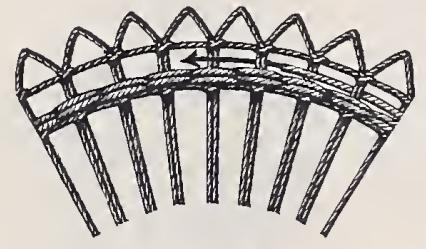

Fig. 8.

Braid in darning stitch.

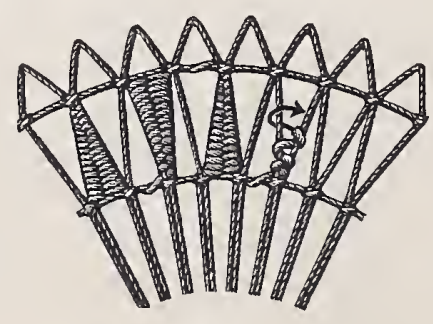

Fig. 9.

Points in darning stitch.

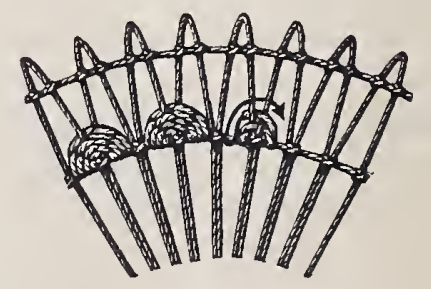

Fig. Io. Scallops in darning stitch.

The different kinds of wheels are so much used in every kind of embroidery that we take it for granted that they will be familiar to our readers, and therefore shall not enter here into any fuller description of them.

Circles, braids, points, and scallops in darning stitch (figs. 8, 9, and ro). - In Teneriffe lace, when a less transparent effect is desired, or when it seems desirable to use several shades, circles or braids in darning stitch should be used. The empty spaces between 
two rows of knots can be entirely filled with alternated rows of darning stitch (fig. 8).

Points in darning stitch (fig. 9) are always begun at the point and worked in the ordinary way; the thread, which should as far as possible remain hidden between the points, is carried from one point to the next over the threads of the web.

Fig. Io shows the working of scallops in darning stitch, for which the needle is passed to and fro over several threads of the web meeting in a knot.

Openwork rows in Russian and buttonhole stitch, and bars of stretched threads (fig. Ir). - The spaces, triangular or square in shape, produced by two rows of knots made over the threads of the web, being rather meagre in effect, often need to be ornamented with a filling stitch, preferably Russian or herring-bone stitch (fig. II).

In some cases a row of loops in buttonhole stitch may be made, or bars of thread stretched across between the knotted rows.

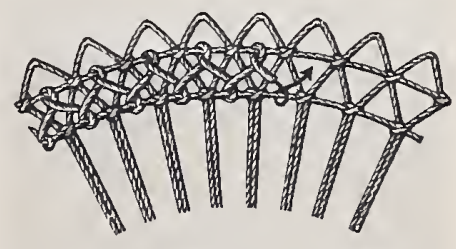

Fig. Ir. Band in Russian or herring-bone stiteh.

Detailed descriptions of the different lace stitches and ornamental figures will be found in the following works of the D.M.C I,ibrary: Encyclopedia of Needlework, Point Lace (La Dentelle Renaissance), Embroidery on Net, Drawn thread work, Ist Series (*).

How to remove the finished work from the mould. - This is done by raising each little point with a crewel needle and slipping it carefully over the metal tooth. Metal discs are fitted with a device by which the work can be removed by a very simple movement.

Imitations made with Teneriffe braids. - Besides Teneriffe lace made entirely by hand on metal or indiarubber moulds, there is an imitation of this lace which is made with a special

(*) See, at the end of this album, the list of publications of the $D \cdot M \cdot C$ L,ibrary, containing a great variety of designs for all kinds of needlework. 
kind of braid called Teneriffe braid. These braids consist of a narrow openwork band, with small picots at the bottom and a row of long loops at the top, through which is run a coarse thread which keeps them in position.

To make the pattern this thread is drawn out and the loops freed. The latter are then joined together in varying clusters to form medallions, insertions and laces, in which they replace the hand-made web of stretched threads.

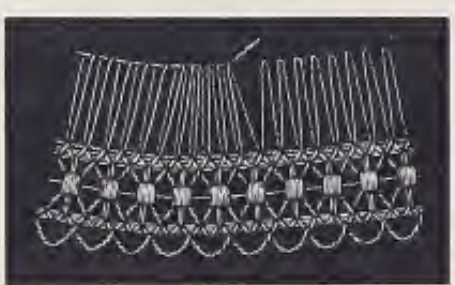

Fig. 12.

Specimen of Teneriffe braid.

Materials. - Teneriffe braids (see fig. I2) are made in several sizes and patterns, in white and écru; they can be obtained at needlework shops.

For drawing the loops of threads together, use $\mathrm{D} \cdot \mathrm{M} \cdot \mathrm{C}$ Cotton lace thread (Fil à dentelles) Nos. 50, 70, or 90; D.M.C Flax lace thread (Lin pour dentelles) Nos. 40, 45, 50, 60, or 70 ; or $\mathrm{D} \cdot \mathrm{M} \cdot \mathrm{C}$ Alsatian thread (Fil d'Alsace) Nos. 50, 60, or 70 ; the same threads are also used for the different lace stitches, and should always exactly match the braid in colour.

Some ornamental stitches, and the decorative figures, which should stand out prominently against the foundation web of threads, should be worked in D.M.C Pearl cotton (Coton perlé) Nos. 3, 5, or 8 , or in $\mathrm{D} \cdot \mathrm{M} \cdot \mathrm{C}$ Rayon for embroidery (Rayonne à broder) Nos. 30 or 60 ; or if desired in a different colour from the braid.

Patterns. - Lace made with Teneriffe braid has to be made according to traced patterns like those used for Point lace. 
These show by a double line where the braid is to be placed, and by small strokes on the outer line the positions of the little picots that finish off the work. Any other indications inside the circles, bands, or scallops are superfluous.

How to join the loops of the braid with crochet stitches (figs. I3 and I4). - After the thread that holds the loops has been withdrawn (see fig. I2), these latter are grouped together

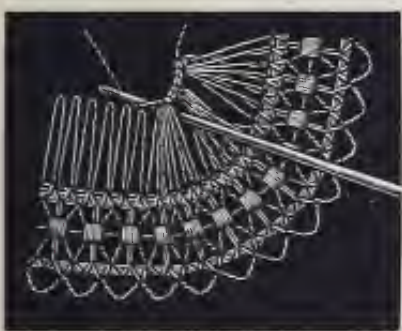

Fig. 13 .

Loops joined in clusters by a double crochet. in the number of clusters required by the pattern to be worked.

This is most easily done with a crochet hook; in fig. I3 the loops mounted on the crochet hook are joined together by a double crochet, while fig. I4 shows how to twist the cluster of loops once round itself. The clusters may also be crossed over each other, and so on.

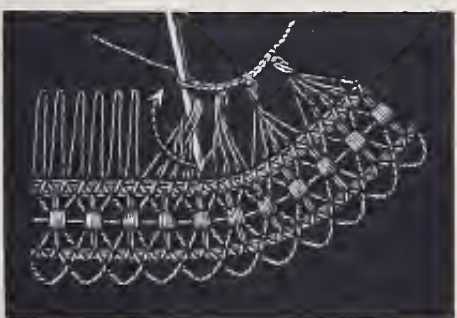

Fig. 14 ,

Loops joined by a double crochet i11 clusters twisted once.

In small medallions the clusters meet

in the centre; in larger medallions, insertions, and edgings, spaces are indispensable and the clusters are connected by small crochet chains.

Tacking down the braids. - The pieces of braid with the loops joined by crochet are laid on the pattern, wrong side uppermost, and fastened with stitches that hold each picot of the braid in the place indicated on the pattern by a small stroke.

The ends of the braids and threads should be finished off as neatly as possible; then the 
inside edge of the braid should be gathered by means of overcast stitches, the fulness being evenly distributed so that the braid will lie perfectly flat.

Making the lace stitches. - The rays, circles, and scallops that form the web of the work are made first.

Over these principal figures the ornamental stitches are then worked, and finally the clusters of loops are crossed and knotted.

How to detach the finished lace from the pattern. - When the work is finished, it is ironed with a warm iron, then detached from the pattern by cutting all the tacking stitches at the back; pull out the ends of thread and the lace will come off of itself.

Plates I to XX. - The plates which follow contain a series of different patterns, representing the principal types of 'Teneriffe lace, some make entirely by hand, others with the help of Teneriffe braids. 

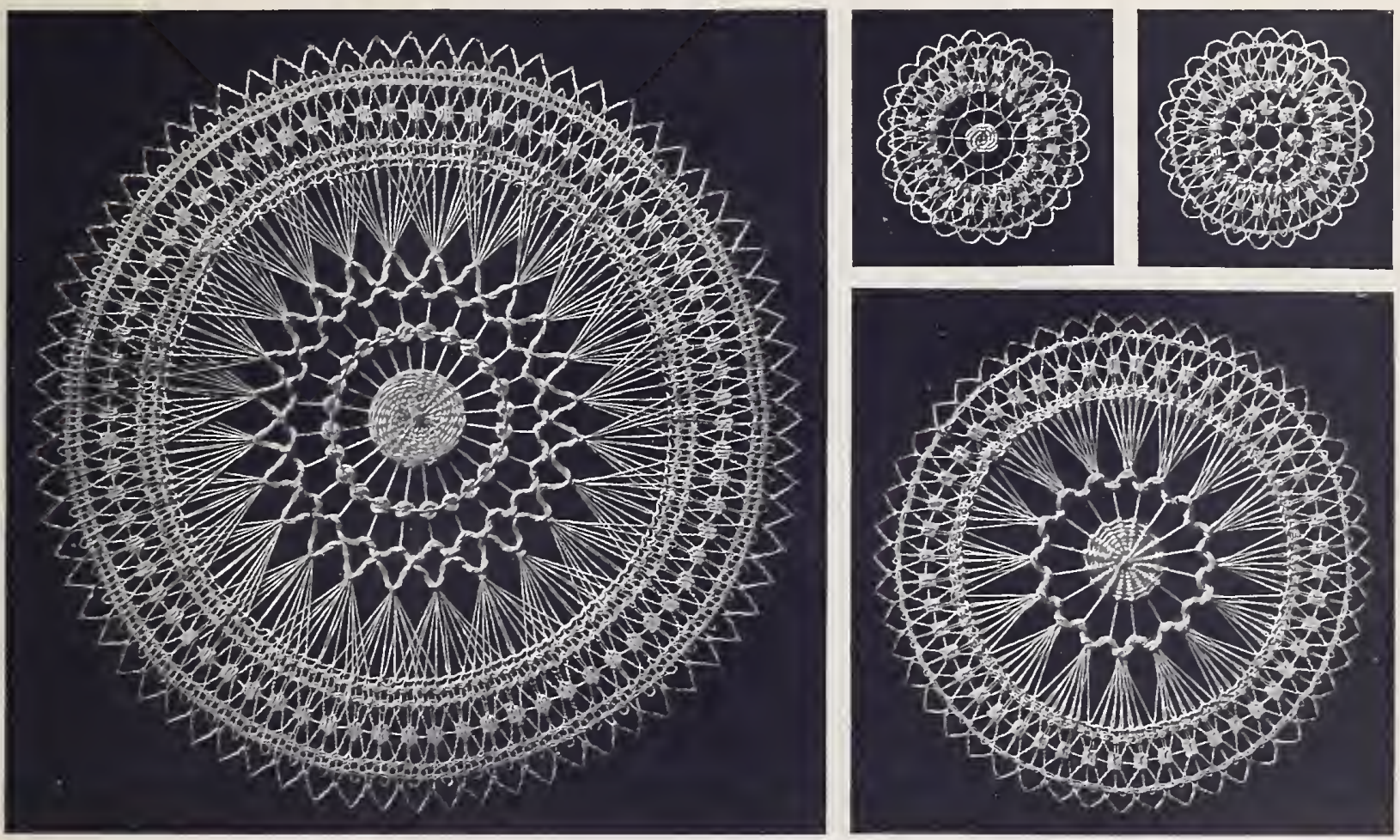

For working, use D.M.C Cotton, Flax and Silk threads

DOILFLS-MIEG \& Cie, Société anonyme

WTLHOT'SE-BELFORT-PARIS 

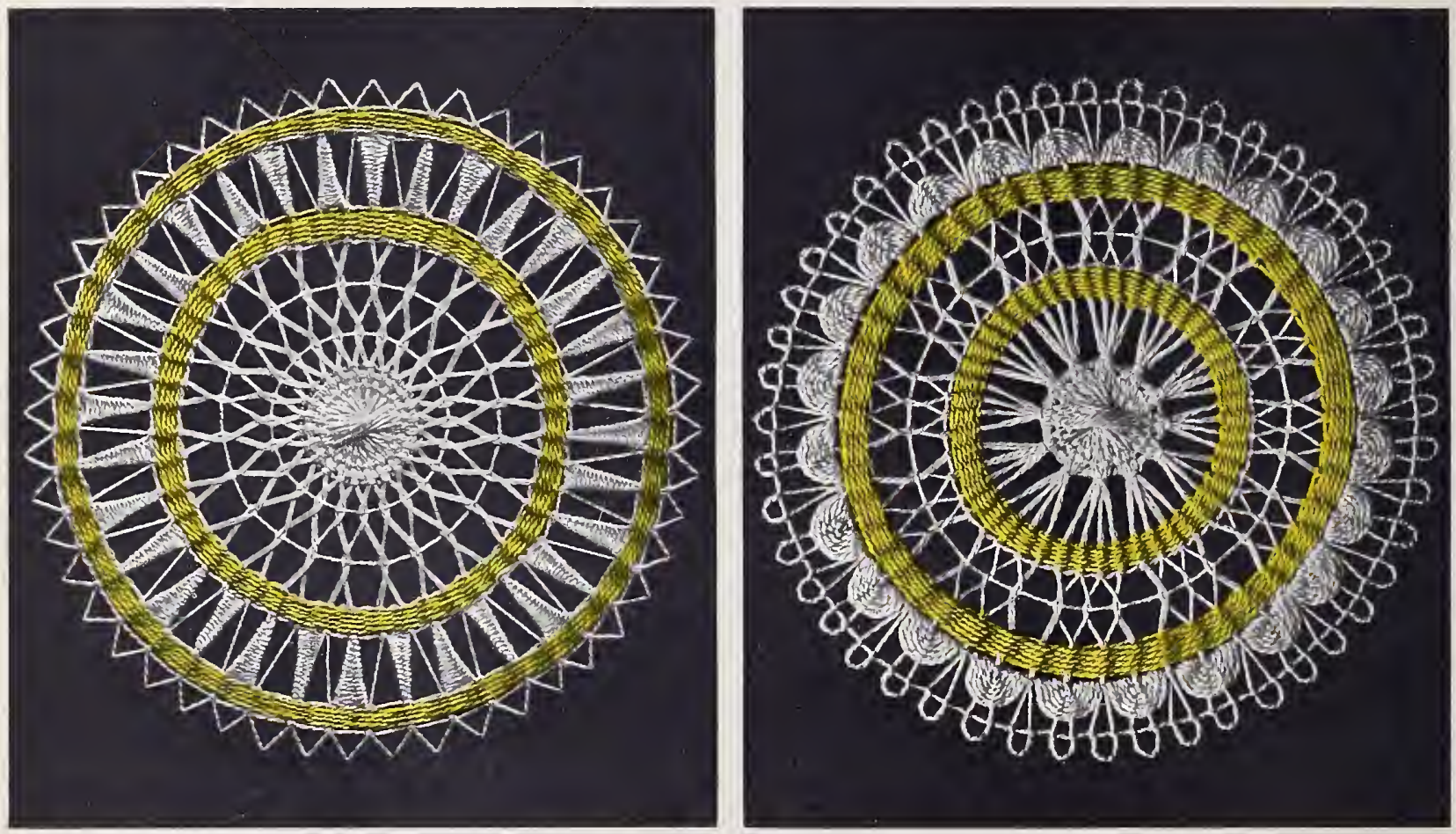

For working, use D.MM.C Cotton, Flax and Silk threads DOLI,FUS-MIEG \& Cie, Société anonyme 

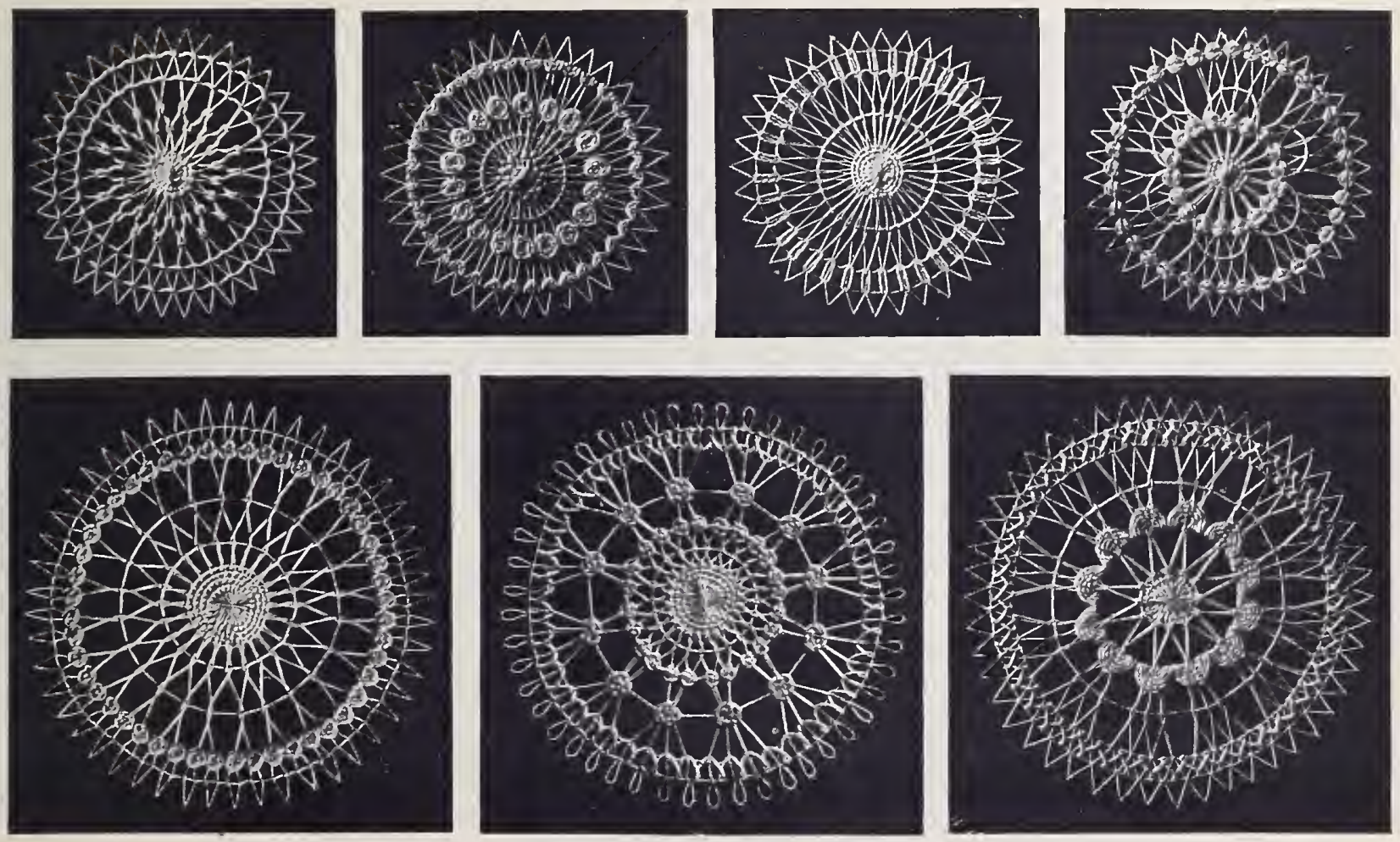

For working, use D.M.C Cotton, Flax and Silk threads

DOLI,FUS-MIEG \& Cie, Société anonyme 

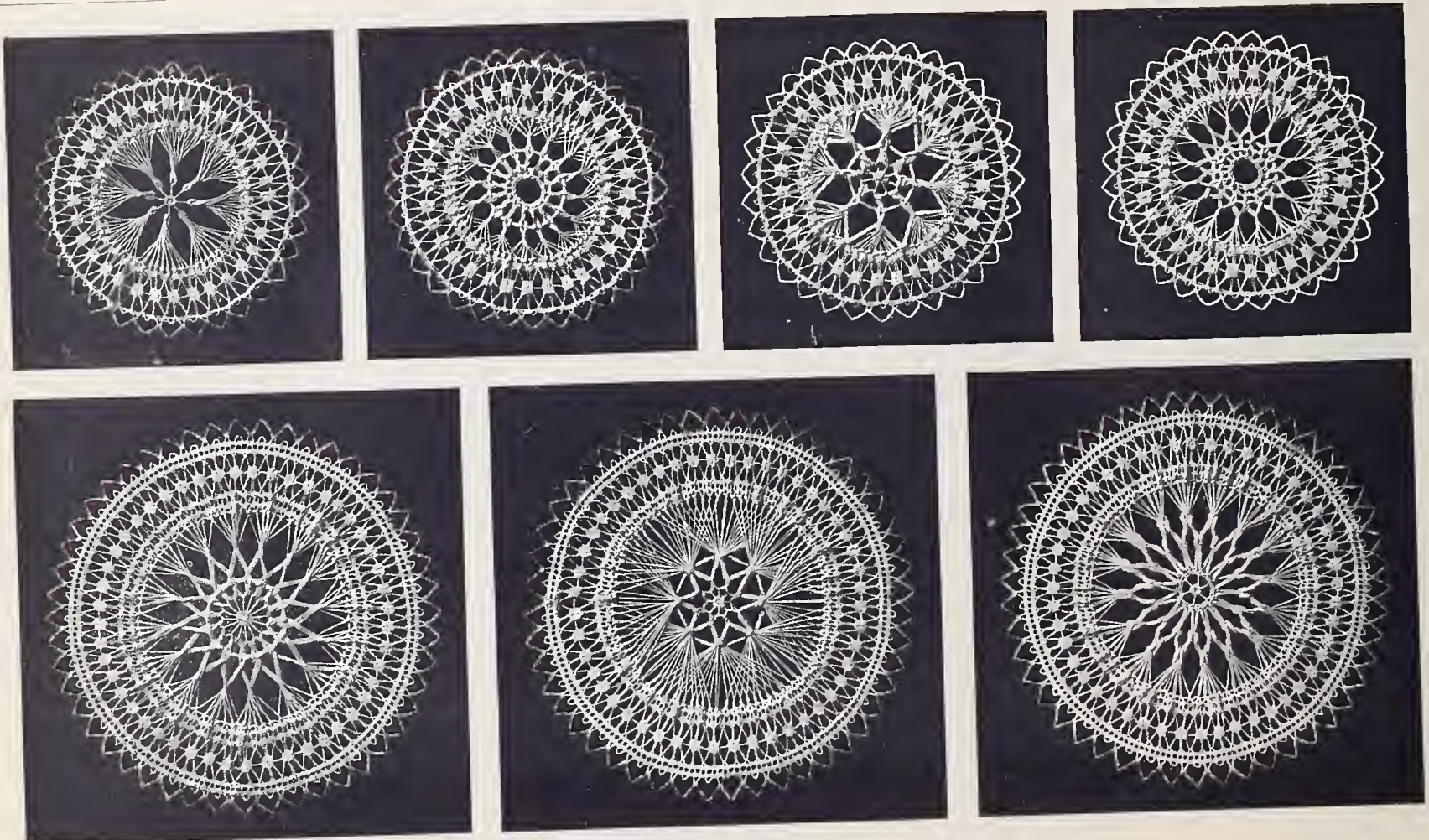

Fior working, use D.MI.C Cotton, Flax and Silk threads

DOLLFUS-MIEG \& Cie, Société anonyme

MULHOUSE-BELFORT-PARIS 

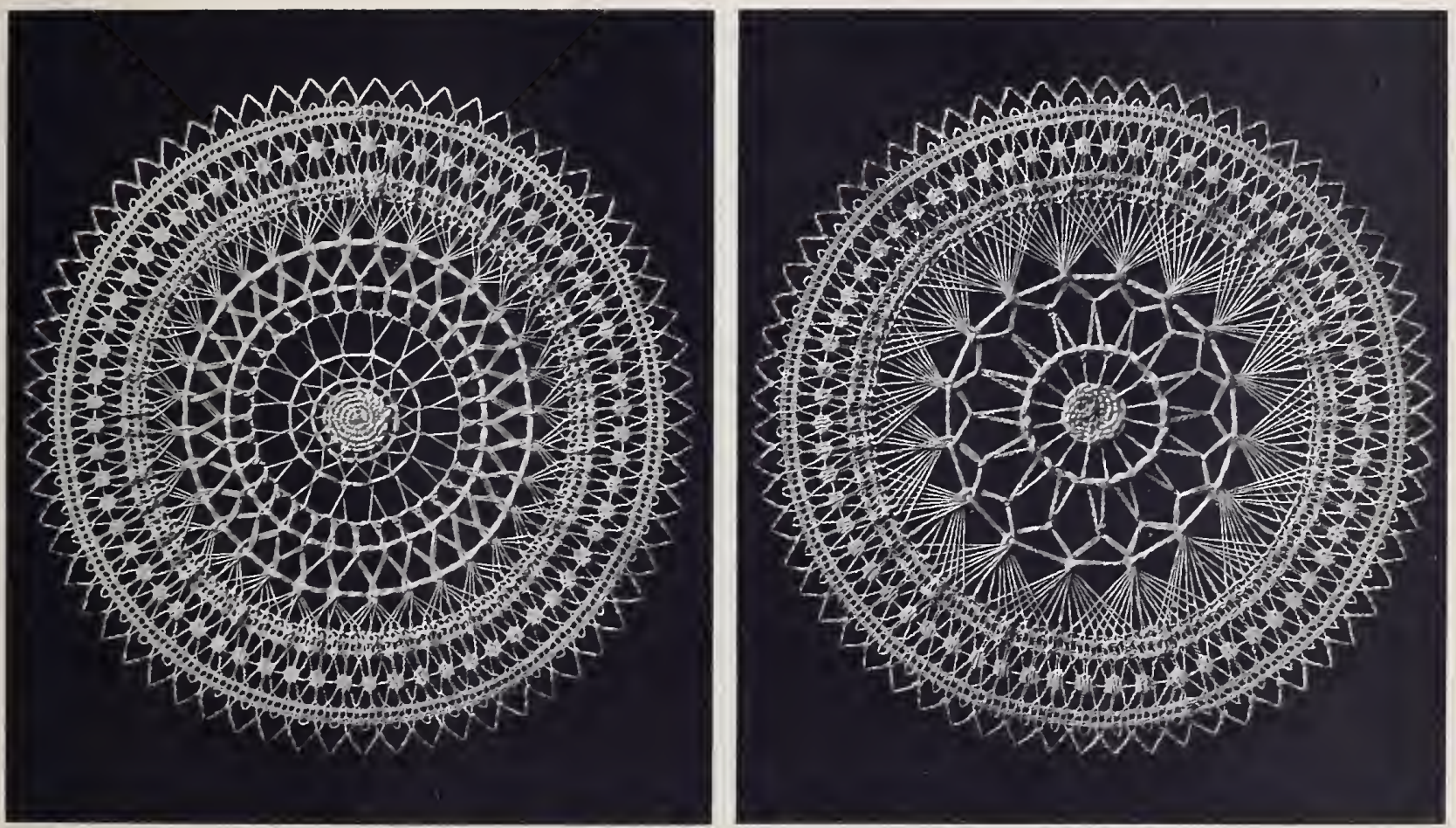

For working, use D.M.C Cotton, Flax and Silk threads

DOLI,FUS-MIEG \& Cie, Société anonyme 

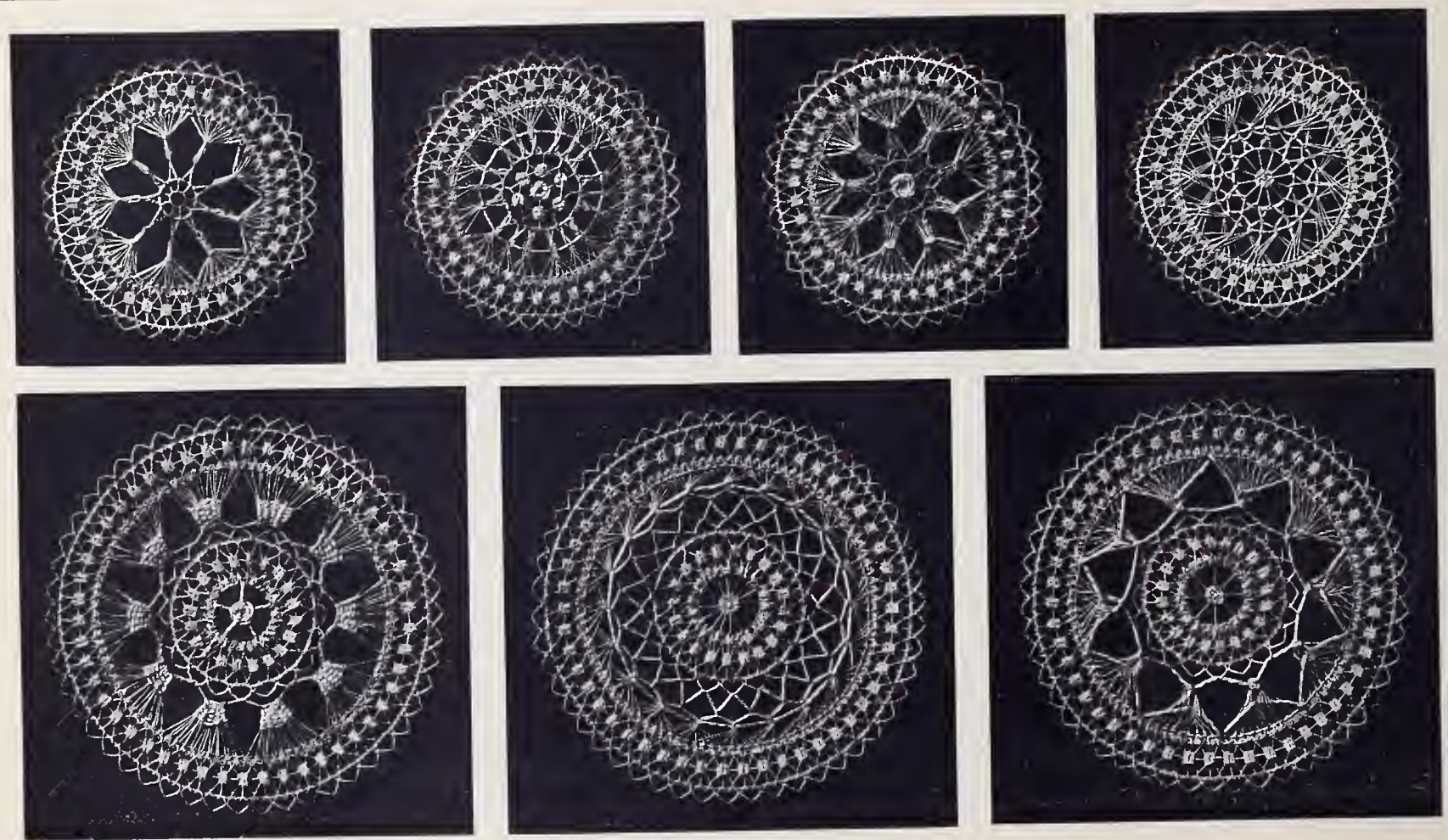

For working, use D.M.C Cotton, Flax and Silk threads

DOLLFUS-MIEG \& Cie, Société anonyme 

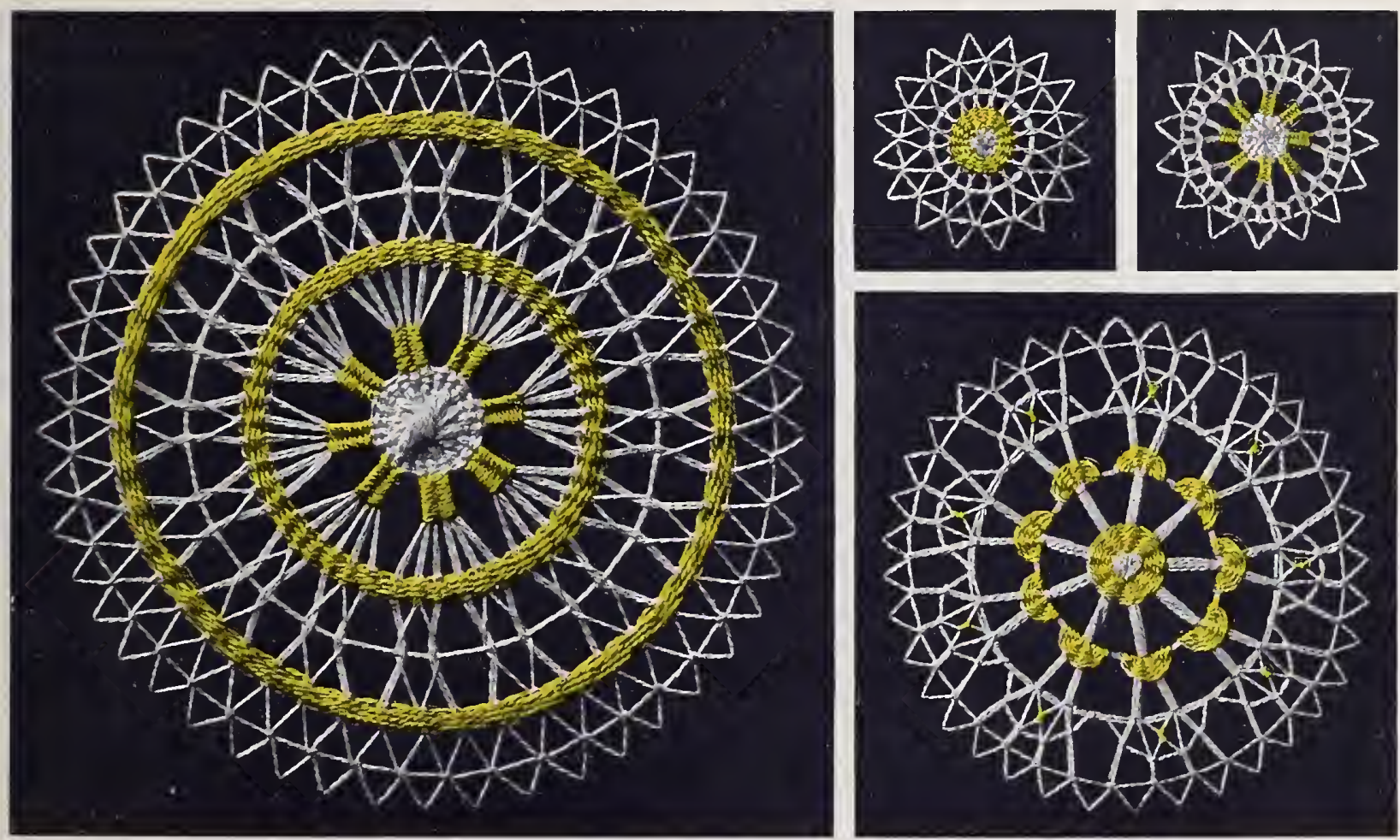

For working, use $\mathbf{D} \cdot \mathbf{M} \cdot \mathbf{C}$ Cotton, Flax and Silk threads

DOI,LFUS-MIEG \& Cie, Société anonyme 

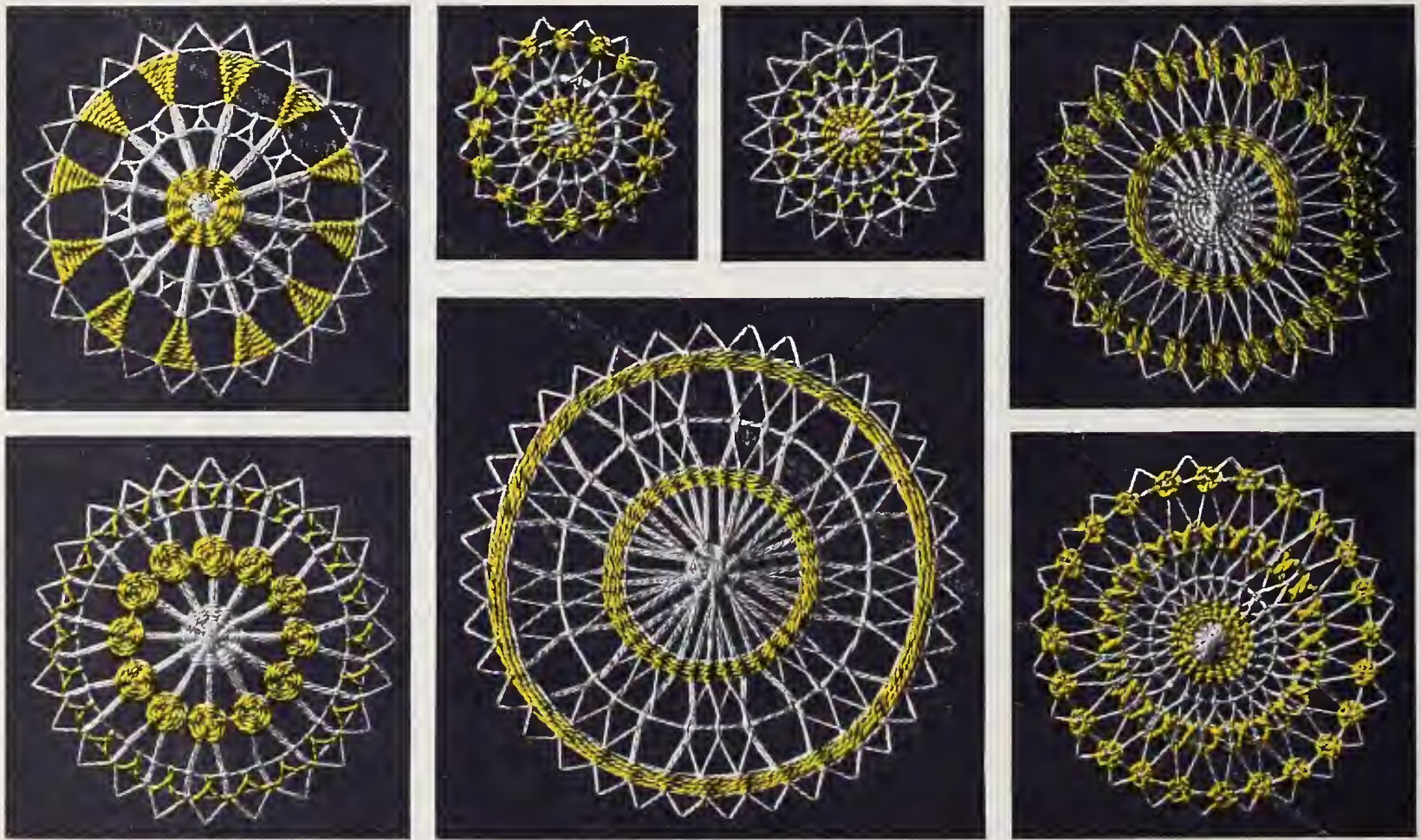

For working, use D·MI.C Cotton, Flax and Silk threads

DOLLFUS-MIEG \& Cie, Société anonyme 

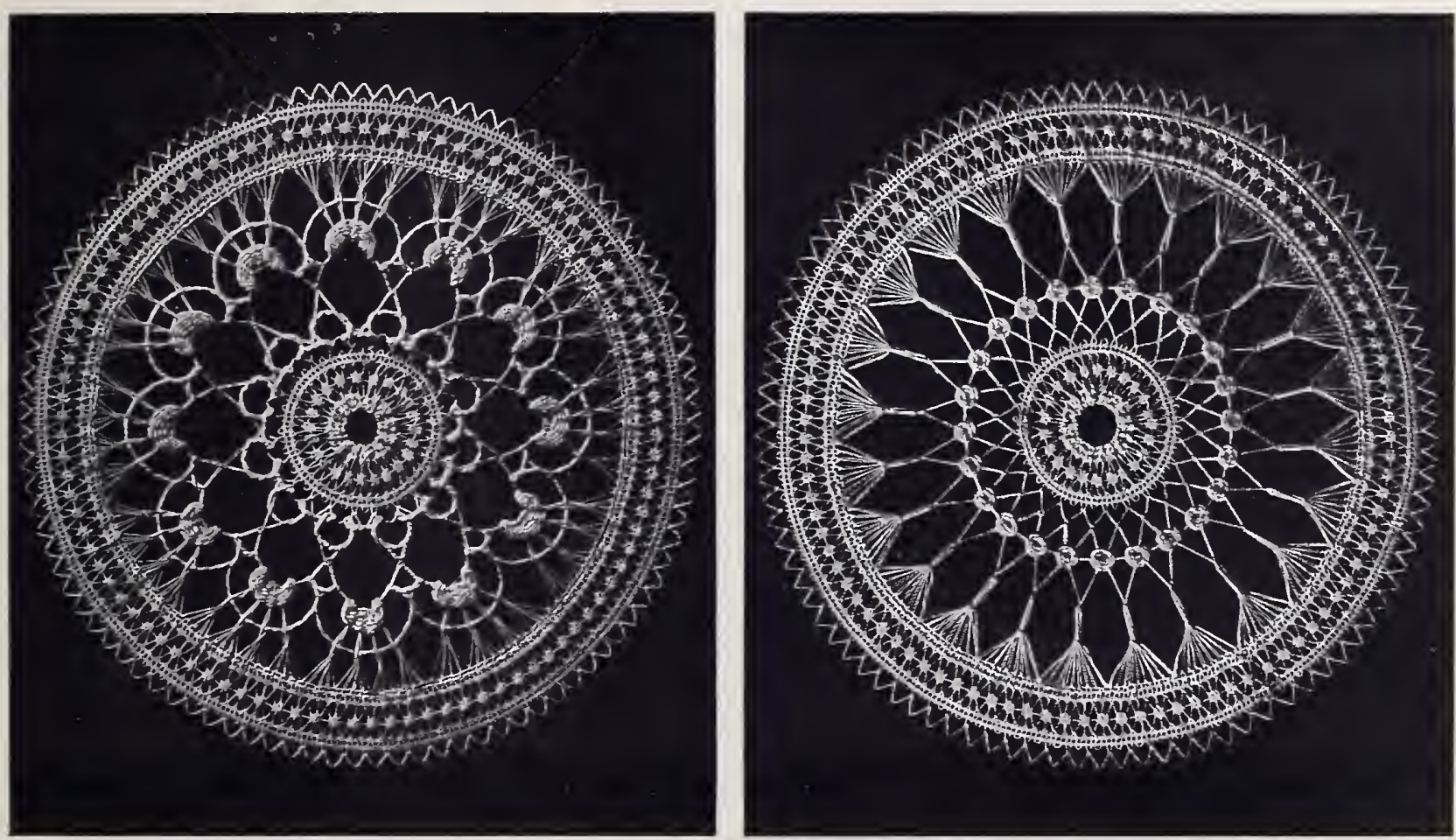

For working, use D.M.C Cotton, Flax and Silk threads DOLLFUS-MIIEG \& Cie, Société anonyme 

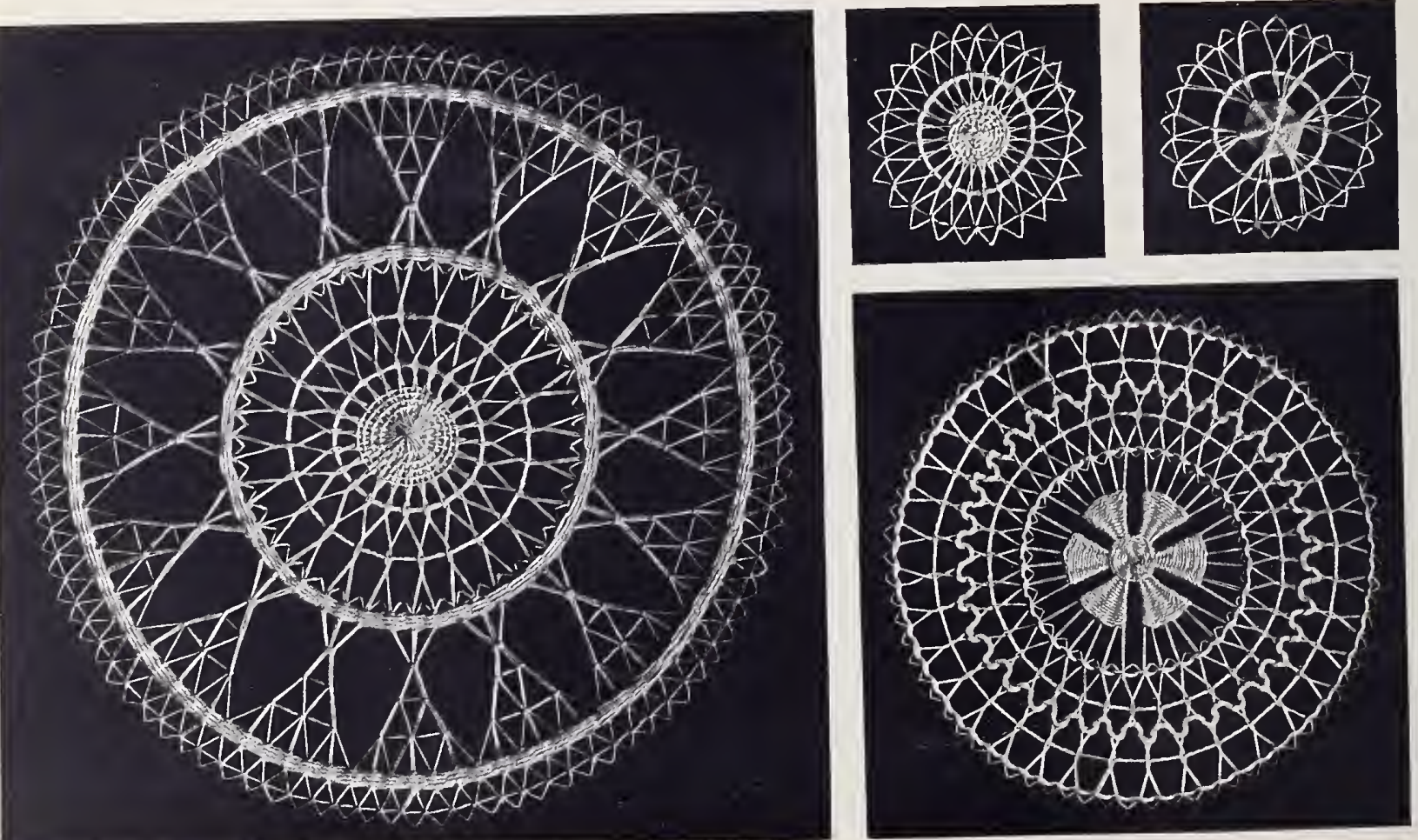

For working, use D·M.C Cotton, Flax and Silk threads DOLLFUS-MIIEG \& Cie, Société anonyme 

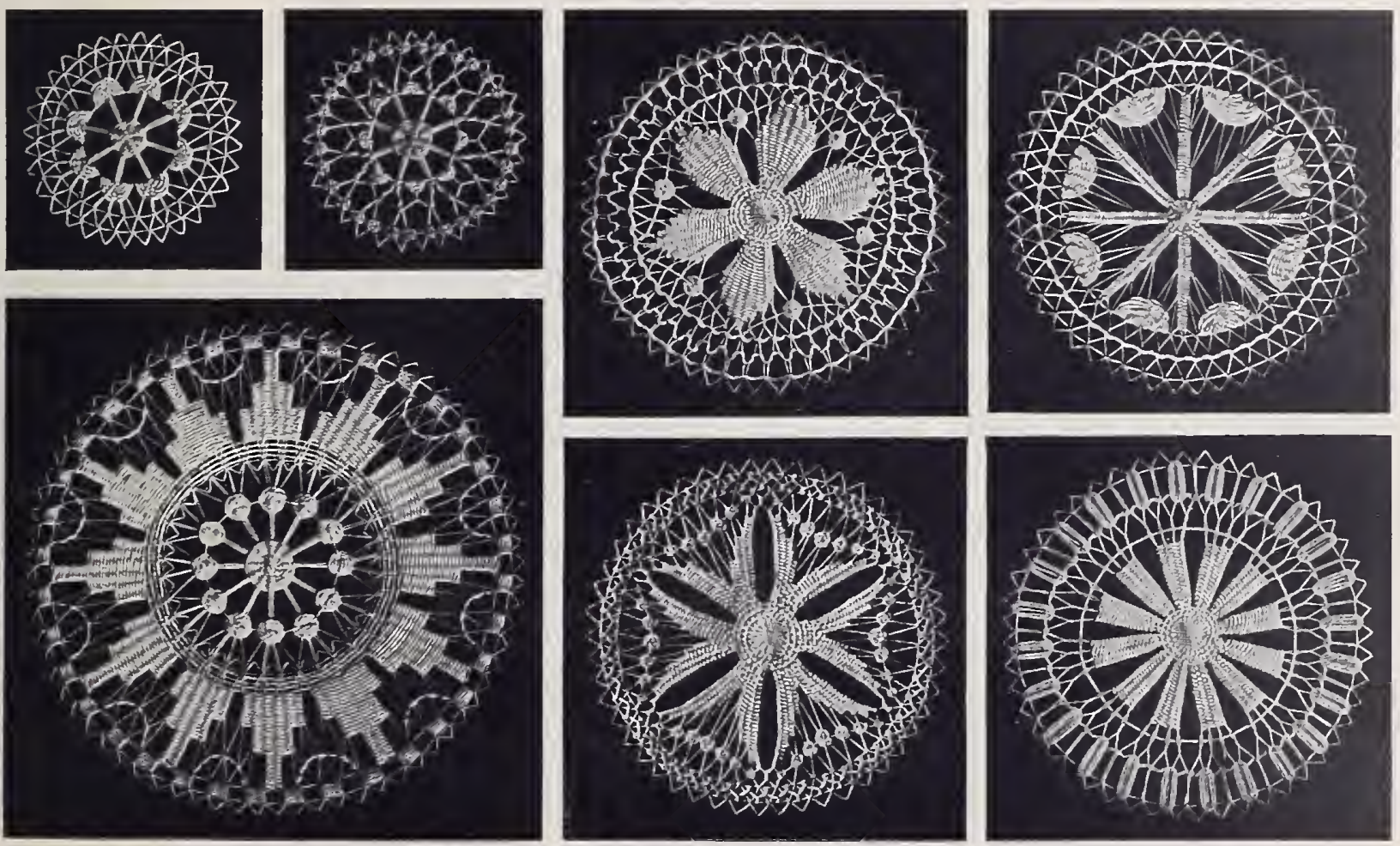

For working, use D.IM.C Cotton, Flax and Silk threads

DOLI,FUS-MIEG \& Cie, Société anonyme

MULHOUSE-BELFORT-PARIS 

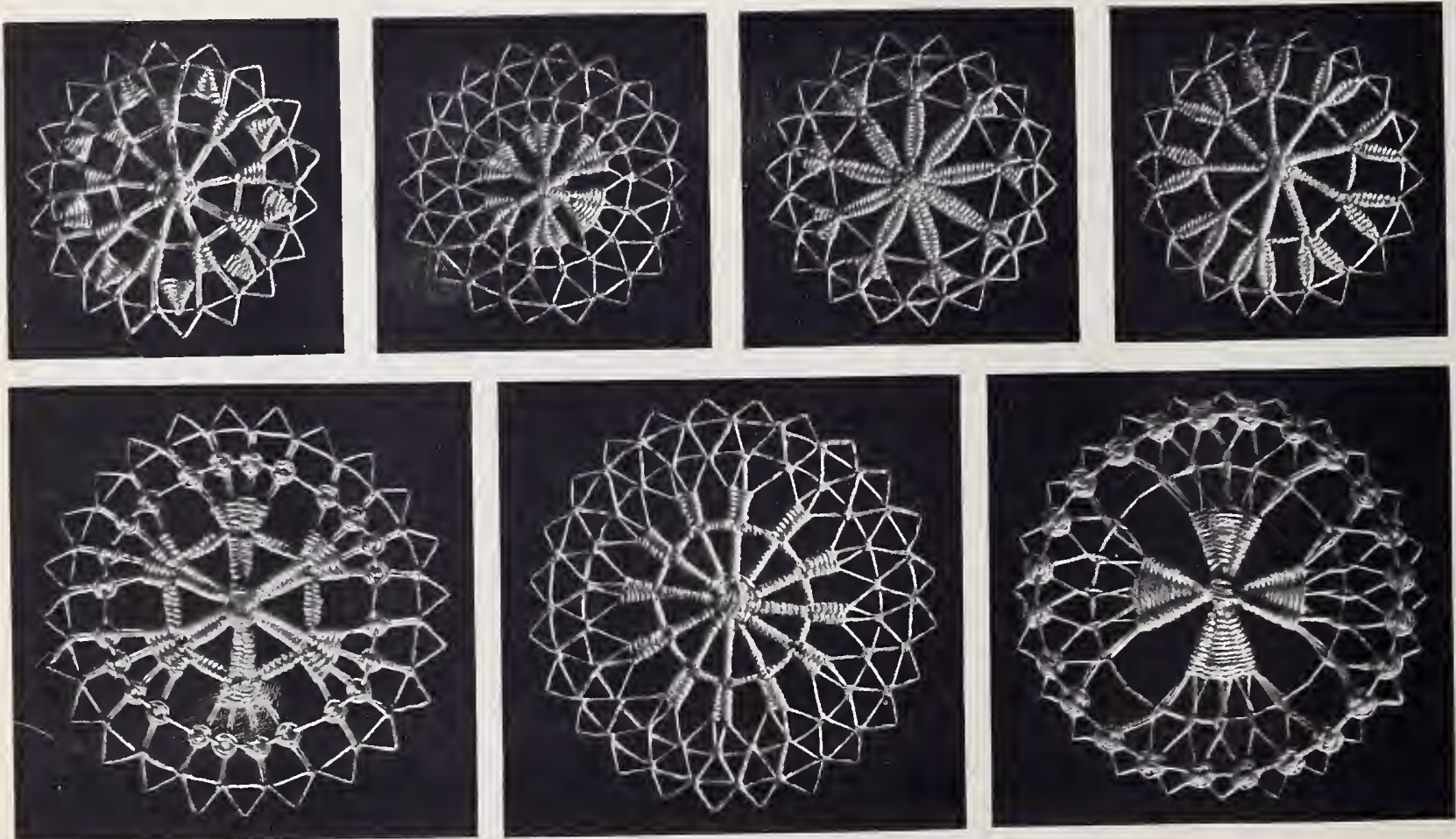

For working, use D.M.C Cotton, Flax and Silk threads

DOLLFUS-MIEG \& Cie, Société anonyme 

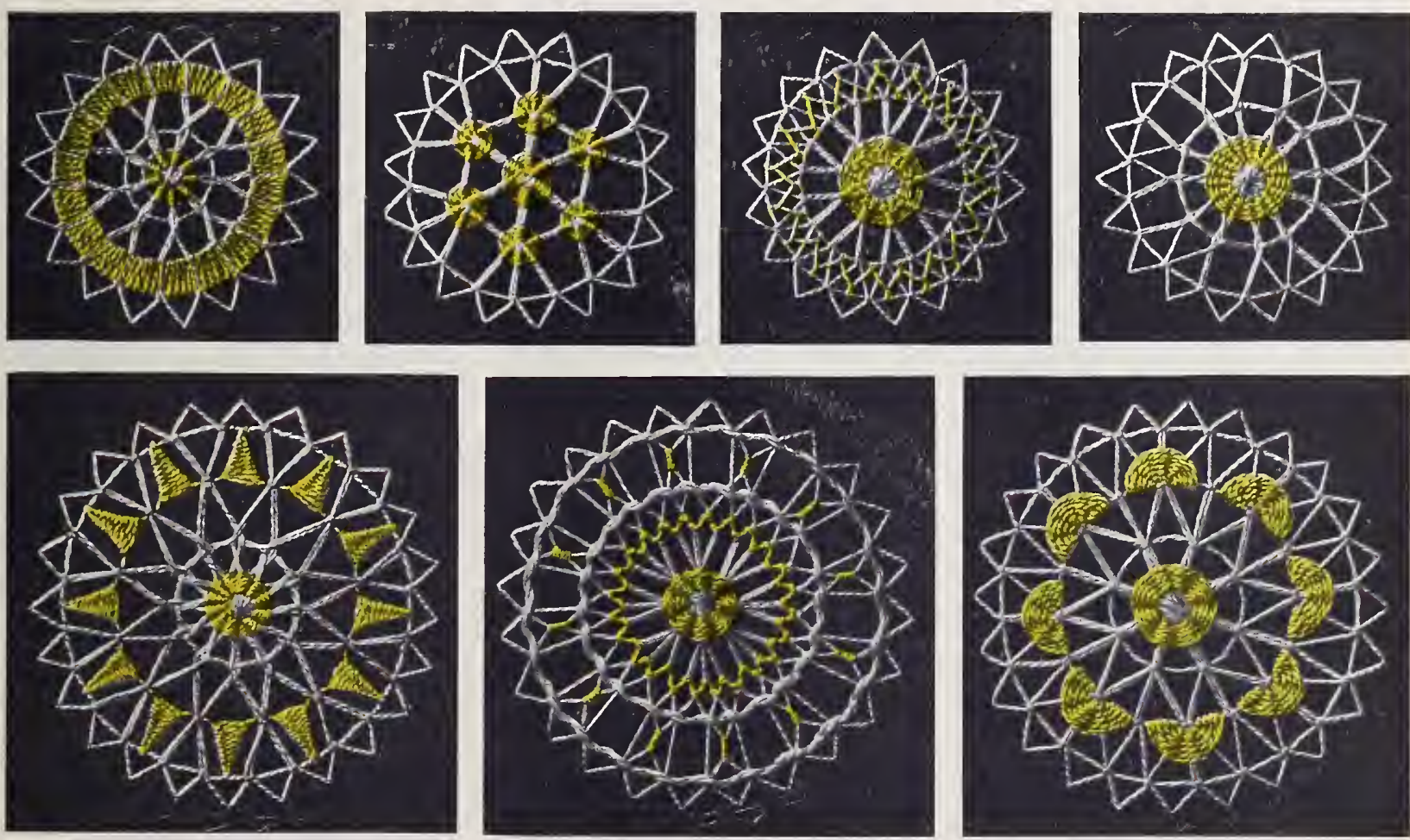

For working, use $\mathbf{D} \cdot \mathbf{M} \cdot \mathbf{C}$ Cotton, Flax and Silk threads

DOLLFUS-MIEG \& Cie, Société anonyme 

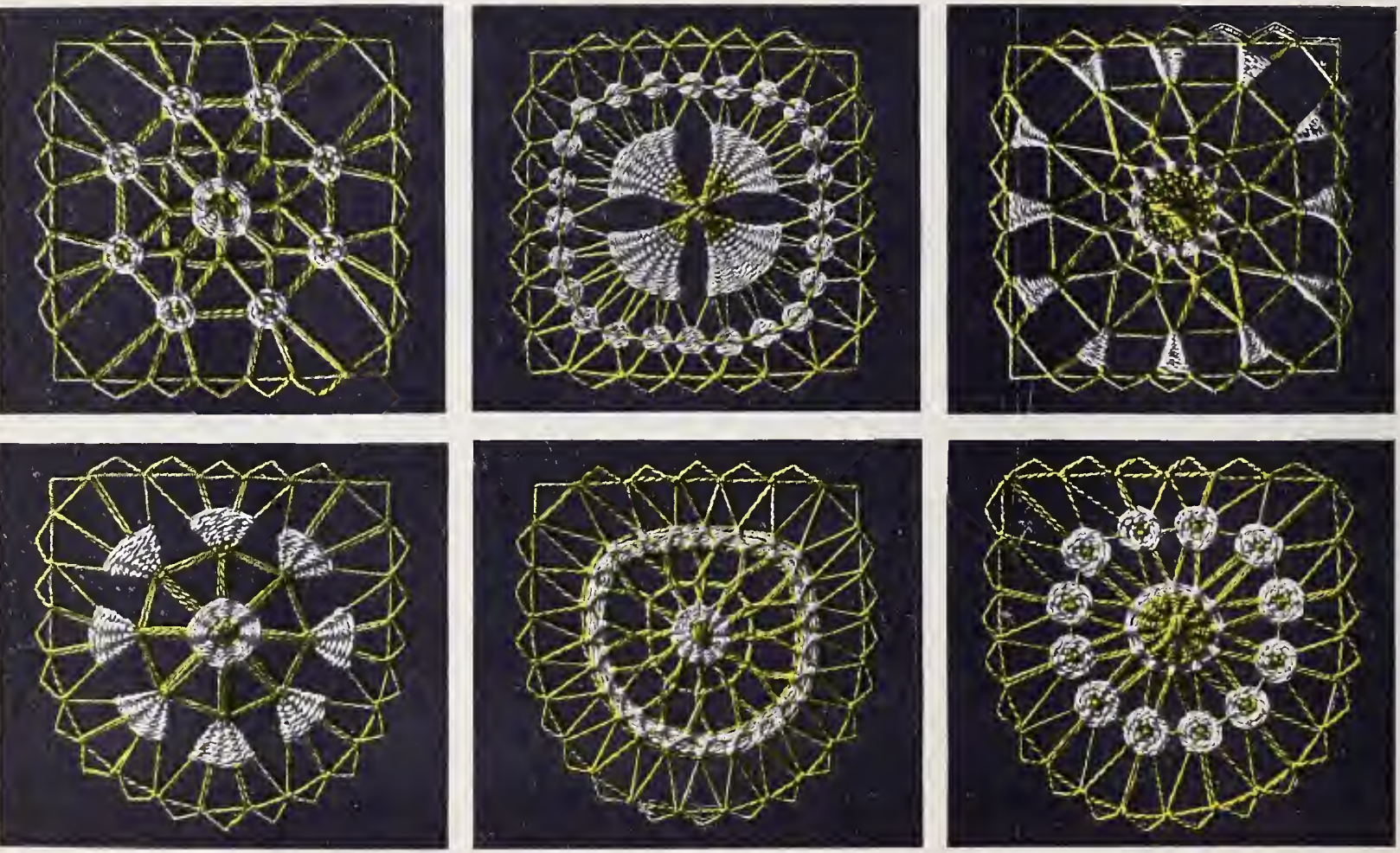

For working, use $\mathbf{D} \cdot \mathbf{M} \cdot \mathbf{C}$ Cotton, Flax and Silk threads

DOLLFUS-MIEG \& Cie, Société anonyme 

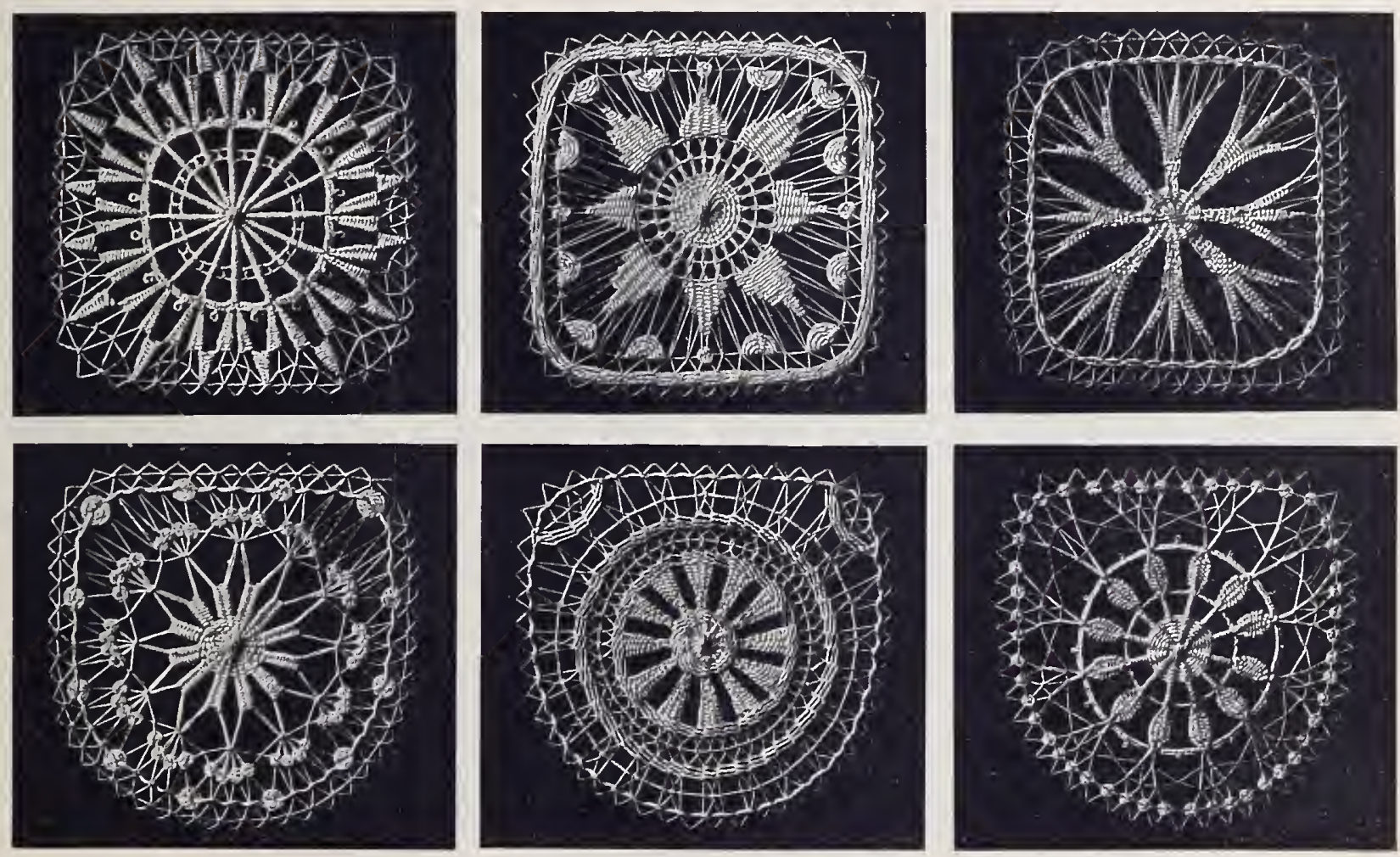

For working, use D·M.C Cotton, Flax and Silk threads

DOLI,FUS-MIEG \& Cie, Société anonyme 


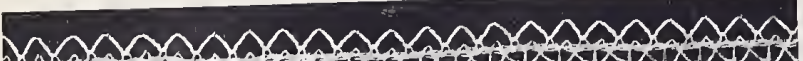

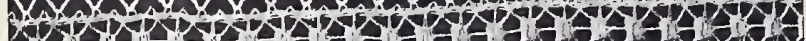

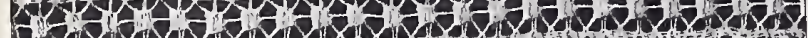

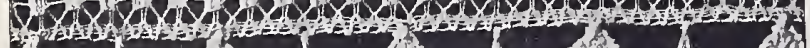
to

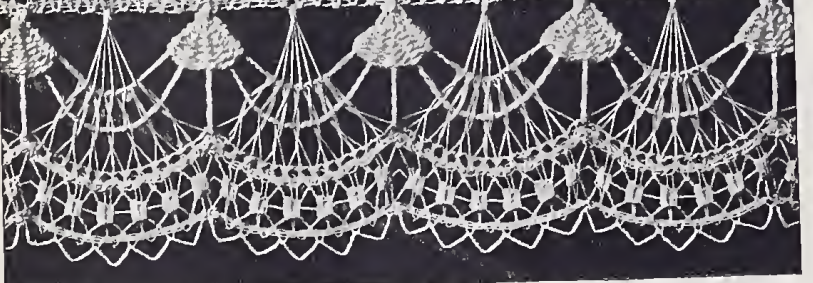

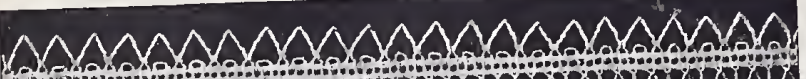
(1) (1)

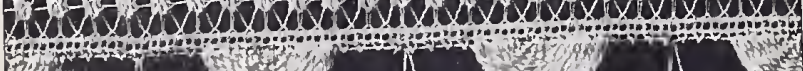
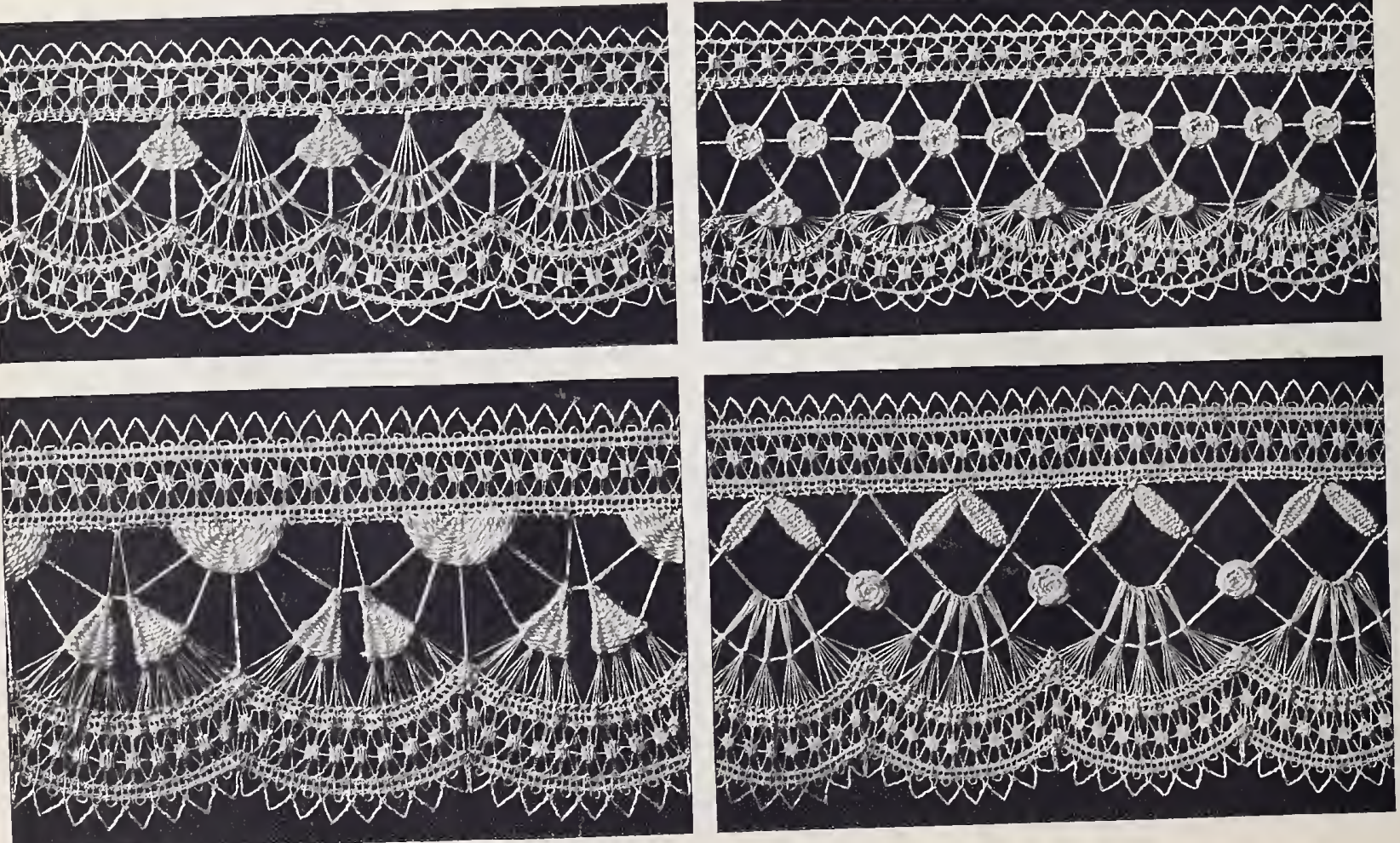

For working, use D.M.C Cotton, Flax and Silk threads

DOLLFUS-MIEG \& Cie, Société anonyme 


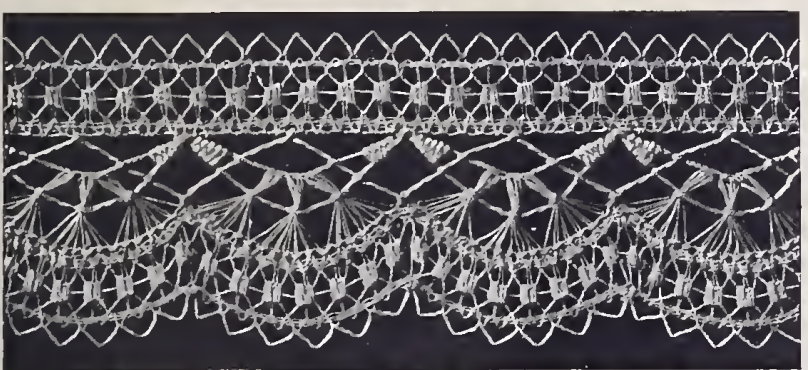

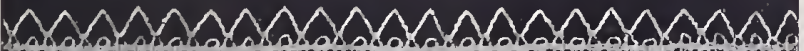

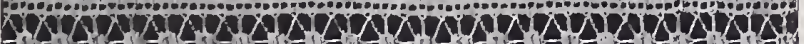

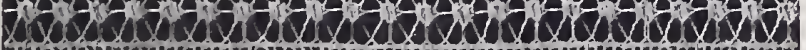

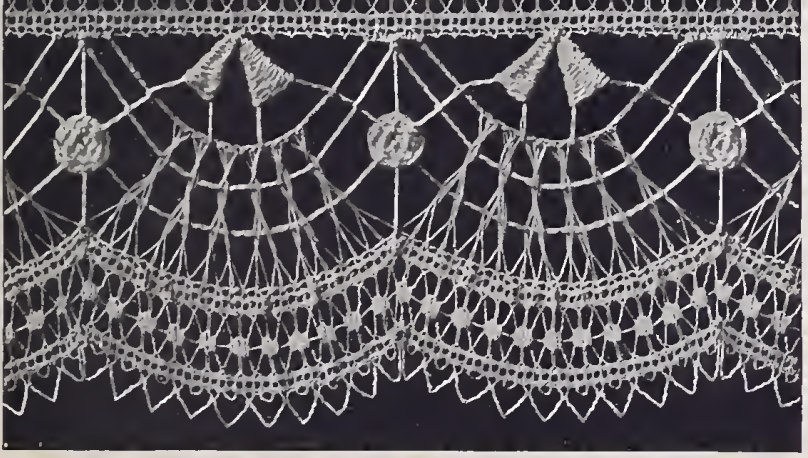

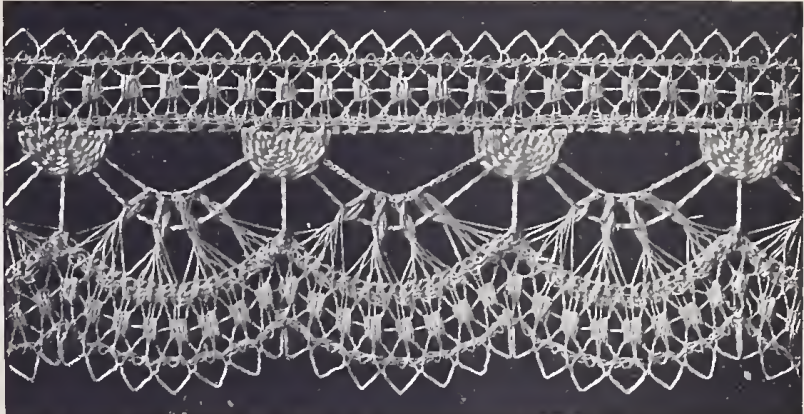

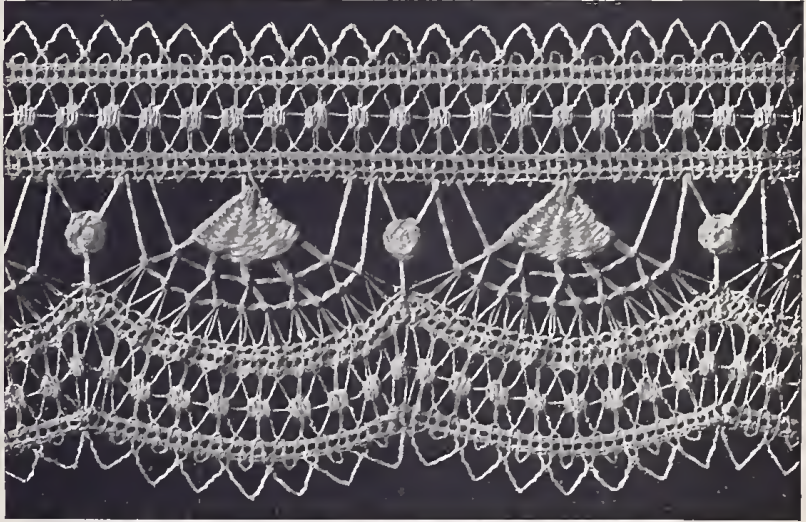

For working, use D.M.C Cotton, Flax and Silk threads

DOLLFUS-MIEG \& Cie, Société anonyme 

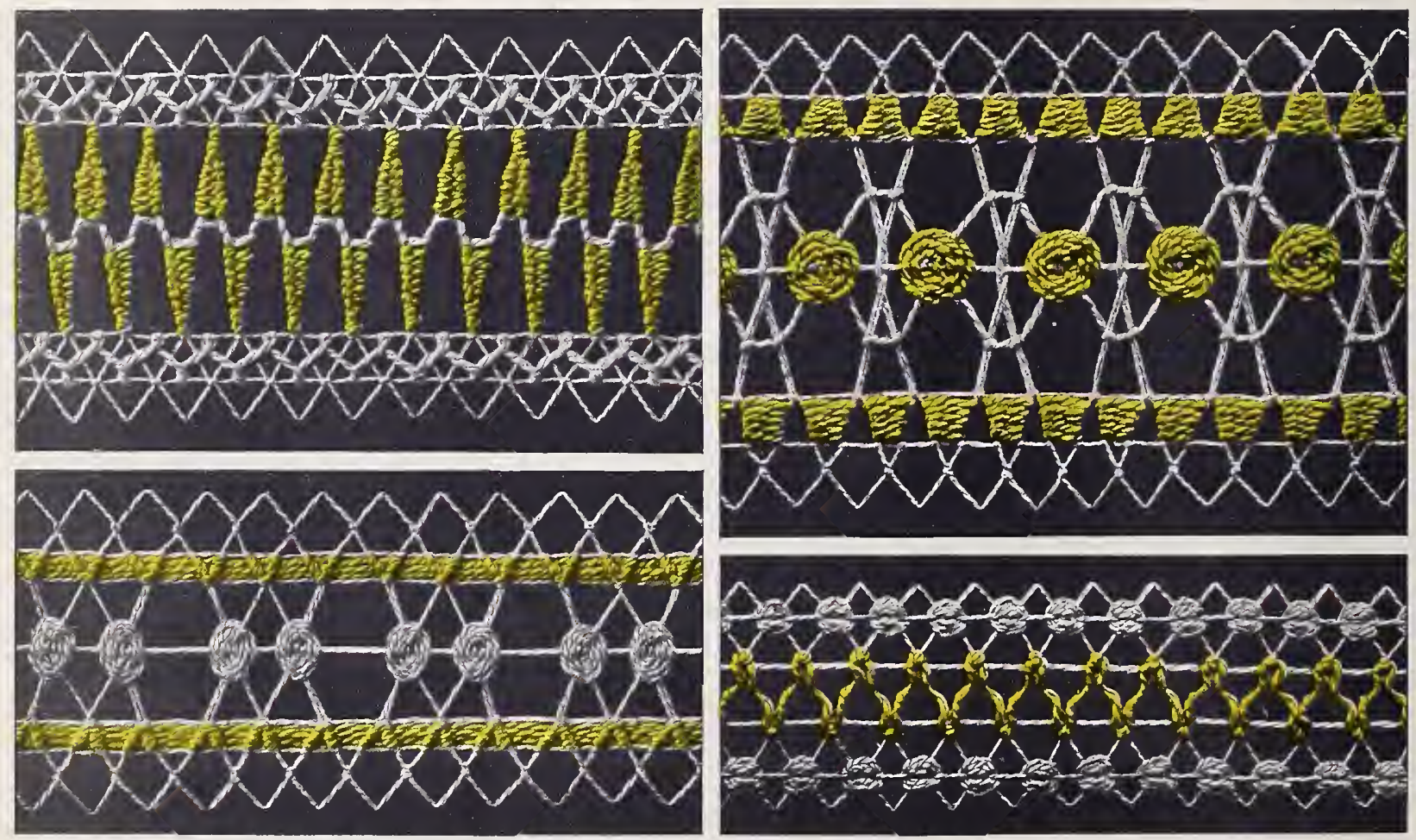

For working, use D.IM.C Cotton, Flax and Silk threads

DOLLFUS-MIEG \& Cie, Société anonyme 

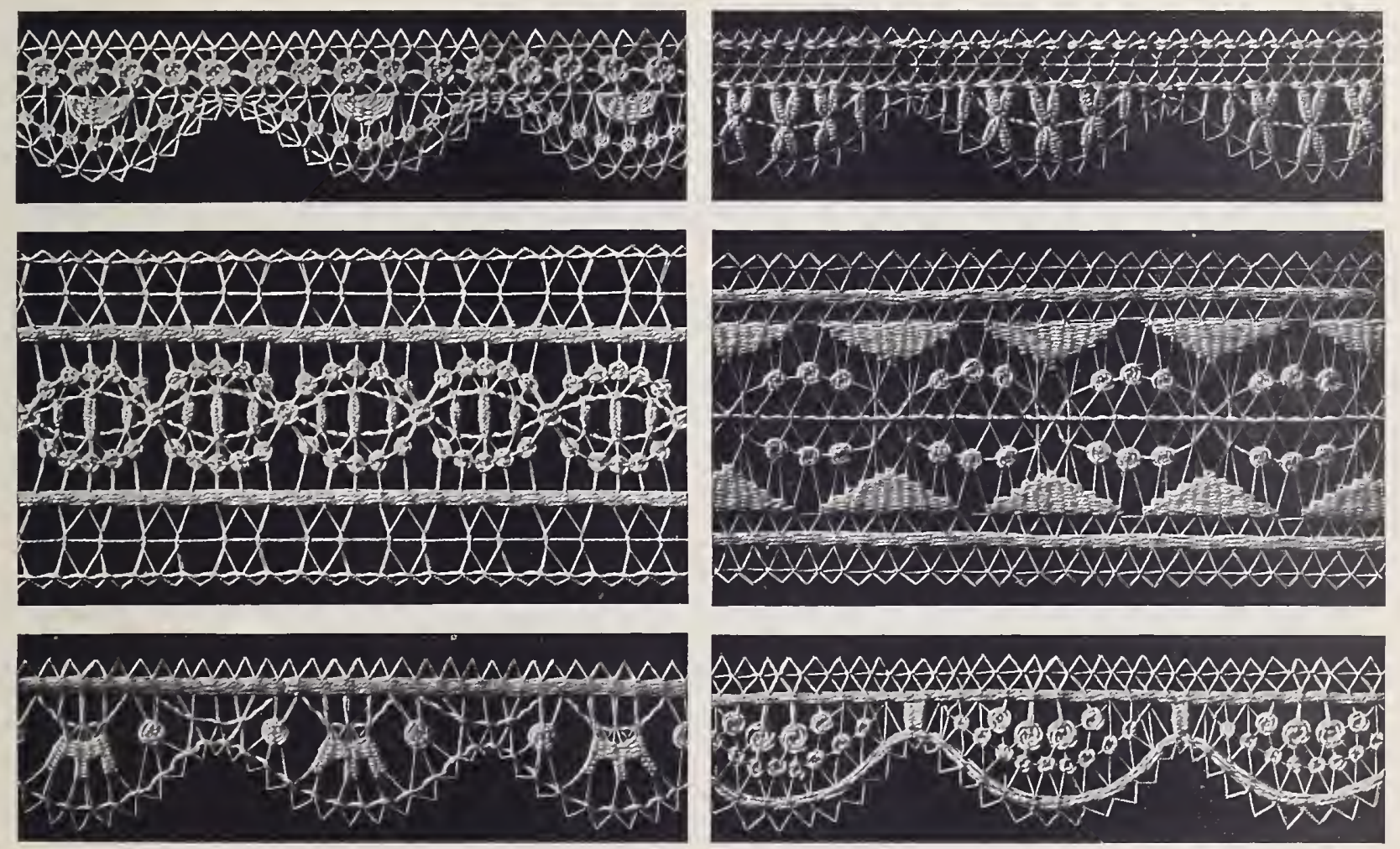

For working, use D·M.C Cotton, Flax and Silk threads

DOLLFUS-MIEG \& Cie, Société anonyme 

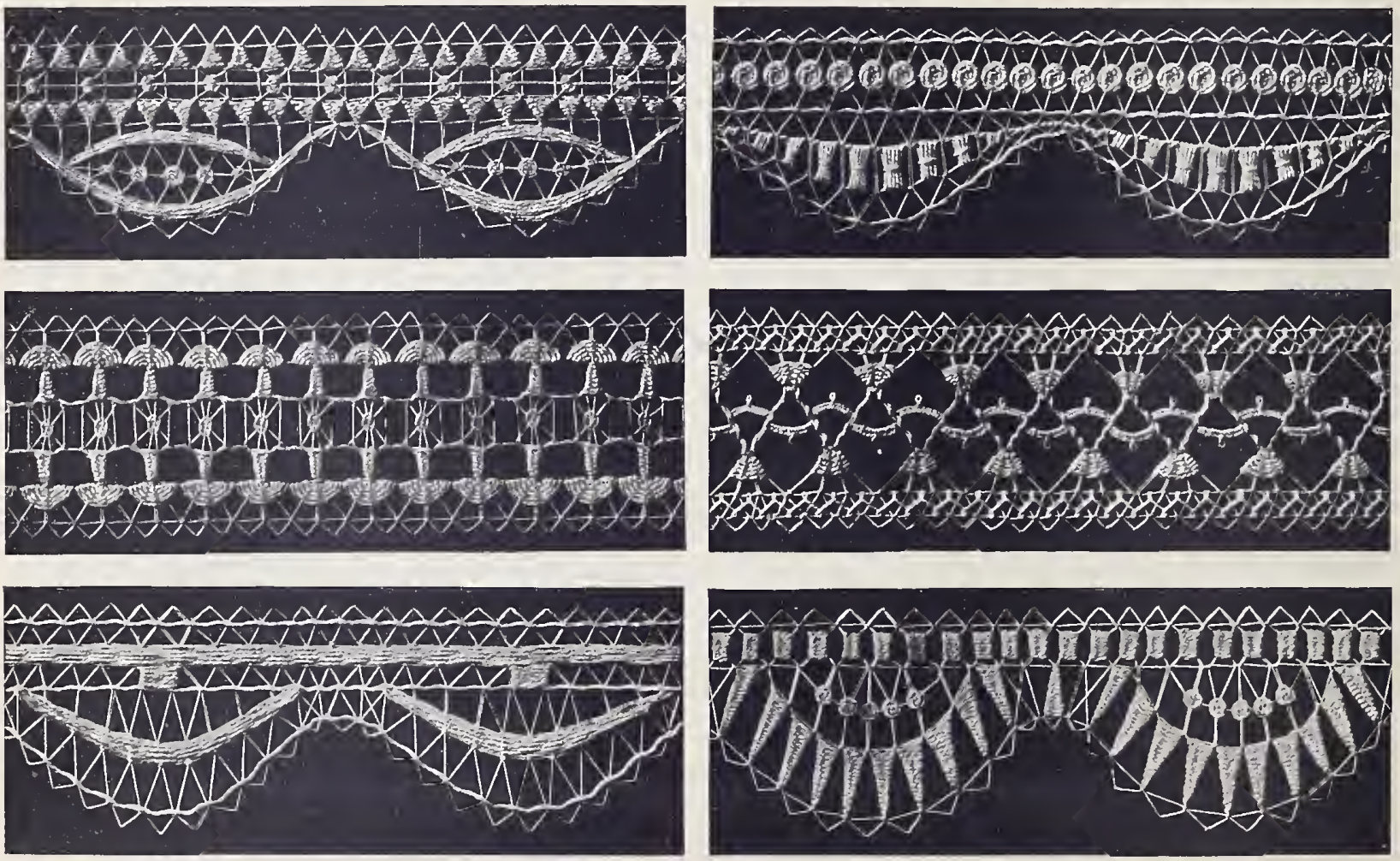

For working, use D·M.C Cotton, Flax and Silk threads

DOI,IUS-MIEG \& Cie, Société anonyme 


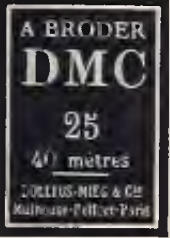

\section{DOLLFUS-MIEG \& C SOCIÉTÉ ANONYME} MULHOUSE-BELFORT-PARIS

manufacture and put on sale under the trade mark

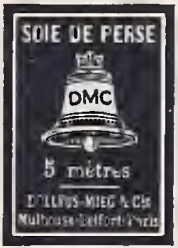

\section{$\mathbf{D} \cdot \mathbf{M} \cdot \mathbf{C}$}

articles specially intended for embroidery, sewing, knitting, crochet and for all kinds of needlework in general, in the following materials:

\section{COTTON, LINEN AND SILK}

These articles are supplied in all sizes in ecru, white, black and all colours.

They can be obtained at the draper's, needlework shops, \&c.; however, the variety of articles bearing the $D \cdot M \cdot C$ trade mark is so great that it is impossible, even for the best furnished shops, to keep them all in stock.

Nevertheless, merchants in touch with the manufacturers, the Socrété ANONYME DolLFUS-MIEG \& Cie, or their agents being able to procure any of these articles, even in fairly small quantities, consumers can always be supplied through them with what they require. 


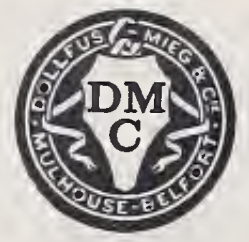

\section{LIST OF THE ARTICLES}

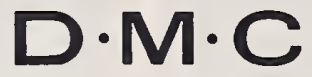

intended for embroidery,

sewing, knitting, crochet, lace work, \&c.

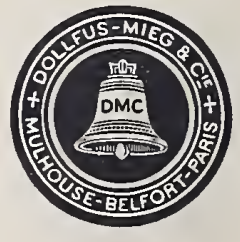

Cottons for embroidery and tapestry : $\mathrm{D} \cdot \mathbf{M} \cdot \mathrm{C}$ Embroidery cottons (Cotons à broder). D.M.C Embroidery twist (Retors à broder). $\mathrm{D} \cdot \mathrm{M} \cdot \mathrm{C}$ Floss embroidery cottons, special quality (Cotons floches à broder, qualité spéciale). $\mathrm{D} \cdot \mathrm{M} \cdot \mathrm{C}$ Pearl cottons (Cotons perlés). $\mathrm{D} \cdot \mathbf{M} \cdot \mathrm{C}$ Shaded pearl cotton (Coton perlé ombré). D·M.C Special stranded cotton (MIouliné spécial). D.M.C Special shaded stranded cotton (Mouliné spécial ombré).

Sewing cottons: $\mathrm{D} \cdot \mathrm{M} \cdot \mathrm{C}$ Alsatian sewing cottons (Fils d'Alsace). $\mathrm{D} \cdot \mathbf{M} \cdot \mathrm{C}$ Bell mark cotton (Fil à la cloche). D $M \cdot \mathrm{C}$ Sewing and machine twist (Câblé 6 fils and Alsa). D.M.C Alsatian cordonnet (Cordonnet d'Alsace).

Crochet cottons: D.M.C Alsatia. D.M.C Cordonnets. D.M.C Crochet cotton, 6 cord, special quality (Cordonnet spécial). $\mathrm{D} \cdot \mathrm{M} \cdot \mathrm{C} 6$ cord cotton lace thread (Fil à dentelles). D.M.C Pearl cottons (Cotons perlés). D $\mathrm{M} \cdot \mathrm{C}$. Shaded pearl cotton (Coton perlé ombré). D.M.C Floss crochet (Crochet floche). D.M.C Kuotting cotton (Fil à pointer).

Knitting cottons: $\mathrm{D} \cdot \mathrm{M} \cdot \mathrm{C}$ Alsatia. $\mathrm{D} \cdot \mathrm{M} \cdot \mathrm{C}$ Retors pour mercerie. $\mathrm{D} \cdot \mathrm{M} \cdot \mathrm{C}$ Knitting twist (Retors pour tricot). D $\mathrm{M} \cdot \mathrm{C}$ Knitting cotton, special quality (Coton à tricoter, qualité spéciale). $D \cdot M \cdot C$ Retors d'Alsace.

Darning cottons: D·M·C Special stranded cotton (Mouliné spécial). D·M·C Darning cotton, special quality (Repriser spécial). $\mathrm{D} \cdot \mathrm{M} \cdot \mathrm{C}$ Superfine darning cotton (Repriser superfin). D.M.C Stranded darning cotton, 8 threads (Coton mouliné doublé, 8 fils).

Embroidery and scalloping machine twist: D.M.C Embroidery cotton (Coton à broder). D.M.C Retors d'Alsace. $\mathrm{D} \cdot \mathrm{M} \cdot \mathrm{C}$ Alsatian cordonnet (Cordonnet d'Alsace).

Cotton braids: D.M.C Superfine braids (Lacets superfins). D.M.C Cotton braids (Lacets, première qualité).

Flax thread for embroidery and tapestry: D.M.C Floss flax or flourishing thread (Lin floche).

Flax threads for knitting, crochet and lace work: D.M.C Flax thread for knitting and crochet (L,in pour tricoter et crocheter). $D \cdot M \cdot C$ Flax lace thread (L,in pour dentelles).

Pure Silk for embroidery: D.M.C Persian silk (Soie de Perse).

Rayon for embroidery: D·M.C Rayon for cmbroidery (Rayonne à broder). 


\section{$D \cdot M \cdot C$ LIBRARY}

In the endeavour to develop the taste for fancy needlework and to make better known the use of the numerous articles made especially for sewing, embroidery, crochet work, knitting, \&c., by the Sociétć anonyme DoLlfus-MrEg \& C'e, the Company has published a series of works, which together form a complete library of information dealing with every known kind of needlework.

Although these publications surpass all that has ever been done in this way before - by their artistic value, the choice of the designs, and the attention applied to their execution - yet, they are sold at a price quite inferior to their real value. They could not have been produced at such favorable prices, had it not been for the numerous editions and the aim they are intended to serve.

Each album is edited in several languages and is composed of a series of unpublished and much varied designs accompanied by explanatory texts.

Ladies who do not find in our assortment the languages with which they are acquainted, will nevertheless be able to use successfully the albums of the $\mathrm{D} \cdot \mathrm{M} \cdot \mathrm{C}$ Library. Owing to the clearness as well as the perfection of the designs, the text becomes a secondary question and it will always be easy to execute most of the patterns shown in these albums without having need of the text.

Further on will be found a description of these publications, which can be obtained of booksellers, mercers and at needlework depôts or direct from the Comptoir ALSAcjen DE Broderie, anc ${ }^{\dagger}$ TH. DE DiLlmont, MulHouse (France).

\section{List of the publications of the $\mathrm{D} \cdot \mathrm{M} \cdot \mathrm{C}$ Library}

* Encyclopedia of Needlework. A handsome volume in-I $6^{\mathrm{mo}}$ of about 800 pages, illustrated by IIo7 engravings and I 3 coloured plates. English binding. Gilt top.

* The ABC of sewing. Pamphlet in-80, I2 pages of text, 23 explanatory illustrations and a plate of letters.

* The ABC of knitting. Pamphlet in $-8^{\circ}$, I 6 pages of text, I 7 explanatory illustrations.

* The ABC of Crochet. Small pamphlet in $-8^{\circ}$, containing 19 pages of text with 23 figures of stitches and patterus.

Albums for Cross Stitch Embroidery, Ist, IInd and IIIrd Series (Albums de Broderies au Point de Croix). Ist Series: 32 plates. IInd Series: 40 plates with coloured designs. IIIrd Series: 40 plates. In $-4^{\circ}$.

(*) The publications marked with an asterisk (*) are edited in English. 
* Cross Stitch - New Designs, Ist Series. Album in-80, containing 24 coloured plates, composed of grounds, borders, \&c.

* Cross Stitch . New Designs, IInd, IIIrd and IVth Series. Three albums in large octavo, each containing 20 coloured plates.

* Cross Stitch - Now Designs, 5th Series. Album in large octavo, containing $x 6$ coloured plates of borders, backgrounds, \&c.

* Cross Stitch - Now Designs, 6th Series. Album in large octavo, containing $x 6$ coloured plates, consisting of borders, all-over and repeating designs, and figure compositions, in modern style, for cross stitch embroidery.

* Marking Stitch, Ist Series. Album in- $8^{\circ}$ of $\mathrm{r} 2$ coloured plates.

* Marking Stitch, IInd, IIIrd and IVth Series. Three albums in-80 each containing I6 coloured plates.

* The Embroiderer's Alphabet. An album in $-16^{\mathrm{mo}}$, containing 82 coloured plates composed of alphabets, monograms and patterns for counted stitch embroideries, followed by ro plates of monograms and scallops with tracings for white embroidery.

The same album is also edited in- $8^{\circ}$.

* Monograms and Alphabets for combination. Album in-80, 31 plates of alphabets for combination and monograms.

Alphabets and Monograms, Ist Series (Alphabets et Monogrammes). Album in-4 $4^{\circ}$, 60 plates with explanatory text. * Alphabets and Monograms, 2nd Series. Album in large octavo, containing 1 y plates and an explanatory text.

Motifs for Embroideries, Ist and *IInd Series (Motifs pour Broderies). Two albums in- $8^{\circ}$, each containing 32 coloured plates, composed of various designs for tapestry and embroidery.

* Motifs for Embroideries, IIIrd and 4th Series. Two albums in large octavo, each containing 20 coloured plates of various designs.

* Motifs for Embroideries, Vth Series. Album in large octavo, 15 coloured plates, a text and a series of drawings.

* Motifs for Embroideries, 6th and 7th Series. Two albums in-80, each containing r 6 coloured plates, composed of various designs in modern style.

* Colbert Embroideries. Album in large octavo, $r 6$ plates printed in colour and a series of drawings.

* Czecho-Slovakian Embroideries. Album in large octavo, 20 plates printed in colour and a series of drawings.

* Jugoslavian Embroideries, Ist and IInd Series. Two albums in large octavo, each containing 20 plates printed in colour.

* Turkish Embroideries. Album in large octavo, 24 plates printed in colour, a text and a series of drawings.

* Bulgarian Embroideries. Album in large octavo, $x 6$ plates printed in colour, consisting of 88 patterns.

* Morocco Embroideries. Album in large octavo, $x 8$ plates printed in colour, composed of $6 \mathrm{r}$ models of borders, grounds and motifs.

* Assisi Embroideries. Album in- $4^{\circ}$, containing 24 plates printed in colour and a text with explanatory figures.

(*) The publications marked with an asterisk $(*)$ are edited in English. 
* Ecclesiastical vestments and Altar linen. Album in large octavo, containing, printed in colour, Io plates and various detailed figures for three sets of vestments, a dalmatic with deacon's stole, a cope, a humeral veil, an altar hanging and sacred linen, as well as an explanatory text. 6 supplemeutary sheets, with plans, designs and tracings for the execution of the articles.

* Irish Crochet Lace. Album in large octavo, 52 pages of text, 7 plates of patterns and tracings on linen.

Crochet Work, Ist and IInd Series (Le Crochet). Ist Series: 8 plates composed of 64 patterns and explanatory text. IInd Series: 8 plates composed of 57 patterns aud explanatory text. In $-4^{\circ}$.

* Crochet Work, IIIrd Series. Album in large octavo, containing 13 plates, 70 pages of explanatory text and numerous figures.

* Crochet Work, IVth Series. Album in large octavo, containing i I plates composed of 57 patterns and 65 pages of text.

* Crochet Work, Vth Series (Coarse crochet). Album in $-4^{\circ}, 9$ principal plates, I 3 supplementary plates and text.

* Crochet Work, VIth Series. Album in $-8^{\circ}, 8$ plates composed of 60 models of lace edgings and narrow insertions.

* Crochet Work, 7th Series. Album in- $8^{\circ}$ of 42 pages, containing 19 patterns, 13 of which are of a quite new type, FILF,T CROCHE;T.

Knitting, Ist and IInd Series (Le Tricot). Ist Series: Io plates with 72 patterns aud explanatory text. - IInd Series: ro plates with 63 patterus and explanatory text. In- $4^{\circ}$.

* Knitting, IIIrd Series. Album in- $8^{\circ}$, containing I 2 plates composed of 46 knitting patterns accompanied by 56 pages of text.

* Knitting, IVth Series. Album in $-8^{\circ}$, containing 5 I patterus, with explanatory text. Additional leaflcts showing finished models.

* Knitting, 5th Series. A large octavo album of 44 pages, containing 15 designs in openwork knitting.

French Net Work (Le Filet-Richelieu). Album in $-4^{\circ}$, 30 plates containing I7 I patterns with explanatory text.

* Embroidery on Net (The Net Work), Ist Series. 26 pages of text and 20 plates with various patterns. In-80.

* Embroidery on Net, IInd Series. Album in $-4^{\circ}$, containing 59 models, a detailed text and explanatory figures.

* Filet-Guipure. Album in large octavo, containing 20 plates with 68 patterns and a text with 17 explanatory figures.

Net Work Embroidery, Ist and IInd Series (La Broderie sur Lacis). Ist Series: composed of 4 I patterus, - IInd Series: composed of 38 patterns. Both with explanatory text. In- $4^{\circ}$.

"Macramé " (Lө IMacramé). Album containing 32 plates, composed of 188 patterns with explanatory text. In-4\%.

* Knotted Fringes. Album in $4^{\circ}$, containing upon 20 plates 20 patterns and a text with explanatory figures.

* Hardanger Embroideries, Ist Series. Album in large octavo, containing 36 plates and a text with explanatory figures. * Hardanger Embroideries, IInd Series. Album in large octavo, containing 25 plates and a text with explanatory figures.

(*) The publications marked with an asterisk $(*)$ are edited in English. 
* Openwork Embroideries. Album in large octavo, composed of 48 patterns and io pages of text.

* Drawn thread Work, Ist Series. Album in $-8^{\circ}$, containing 54 pages of text with explanatory figures and 20 plates of patterns.

* Drawn thread Work, 2nd Series. Album in- $8^{\circ}$, consisting of $x$ I pages of text with explanatory figures and 32 plates of patterns.

Flat Stitch Embroidery (La Broderie au Passé). Album in- $4^{\circ}$, composed of 27 patterns, with tracings and explanatory text.

* Embroidery on Tulle, Ist Series. Album in large octavo, containing 24 plates, 8 coloured, and an explanatory text.

Motifs for Coptic Embroidery, Ist, IInd and IIIrd Parts (Motifs de Broderie copte). Each Part is composed of 30 plates, one coloured, with explanatory text. In- $4^{\circ}$.

Pillow Laces, Ist and IInd Series (Les Dentelles aux Fuseaux). Ist Series, octavo volume, containing I 84 pages of text, 8 plates with patterns of laces, and 55 tracings. - IInd Series, album in large octavo, containing 58 pages of text, 18 plates with 25 patterns, and 66 tracings.

* Needle-made Laces, Ist Series. Album in large octavo, containing 15 platcs, a series of patterns, and a text with explanatory figures.

Point Lace (La Dentelle Renaissance). Album in- $8^{\circ}$, containing 76 pages of text with explanatory figures, Io plates without text and io patterns.

* Teneriffe Lace Work. Album in- $8^{\circ}$, of 20 plates of patterns and a text with explanatory figures.

* Now Patterns in Old Style. Work composed of 12 plates, accompanied by an explanatory text and figures. In- ${ }^{\circ}$.

* Tatting. Album in $8^{\circ}$, containing 8 plates presenting $3^{8}$ models, and a text with explanatory figures.

Works of various kinds (Recueil d'ouvrages divers). Album in- $4^{\circ}$, containing 242 engravings with explanatory text.

(*) The publications marked with an asterisk (*) are edited in English. 


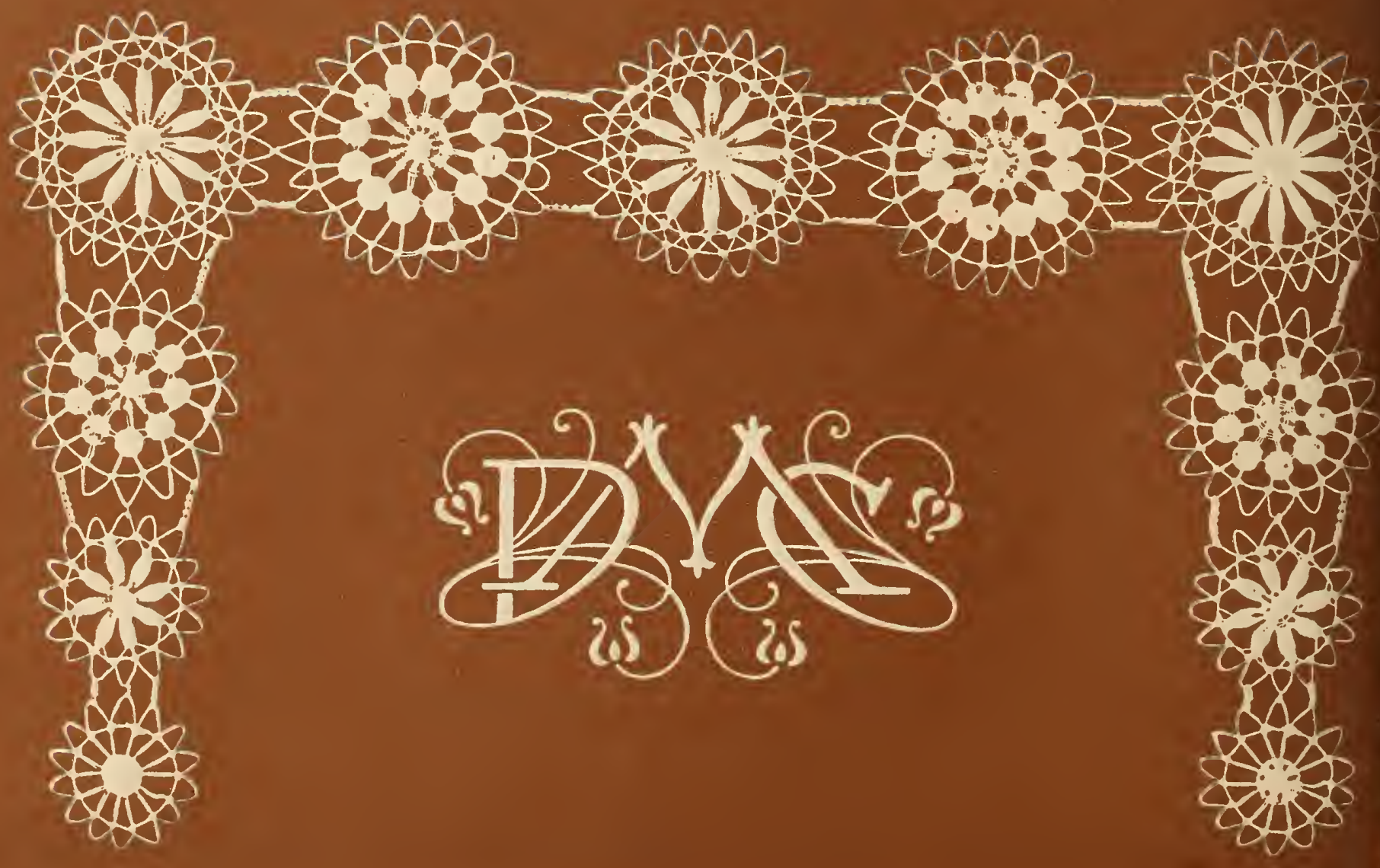




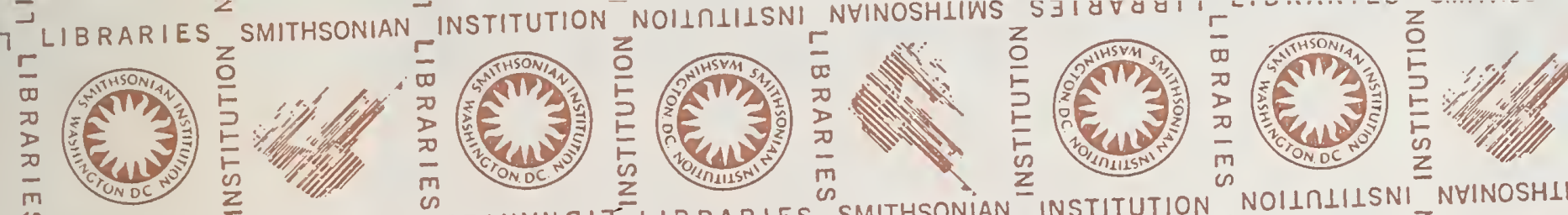

on NOINIIISNI

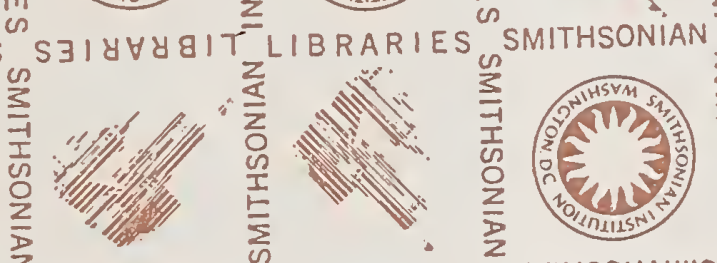

$\sum_{n}{ }_{i}^{2}$
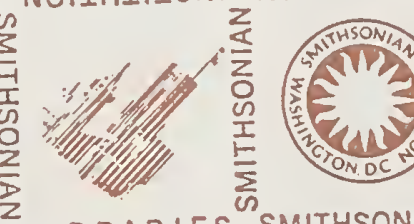

Z IBRARIES SMITHSONIAN
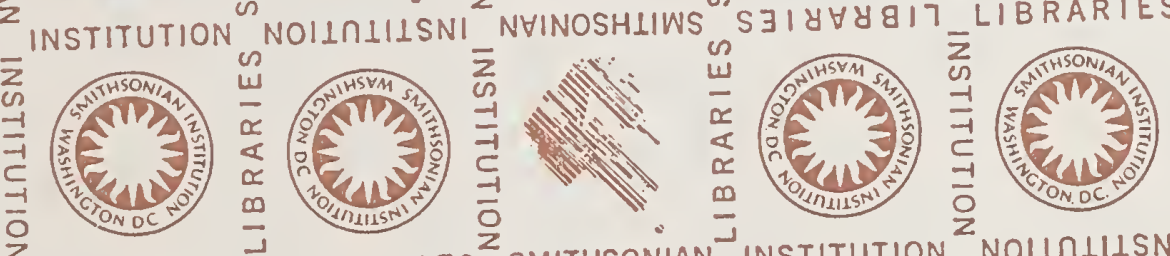

SMITHSON

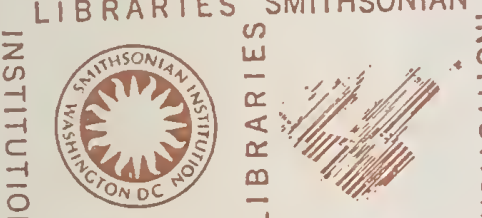

2 NOIINIIISNI NVINOSHLIWS

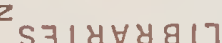

LIBRARIES

SMITHSONIAN INSTITUTION

${ }^{2} \mathrm{NOIOLILSNI}$
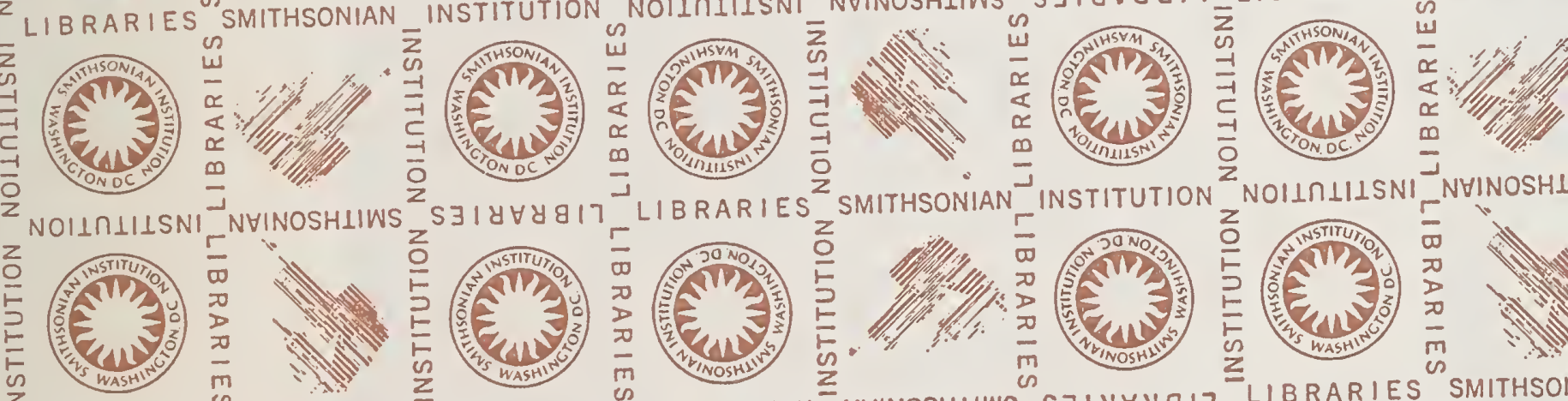

NYINOSHI

LIBRARIES

थ

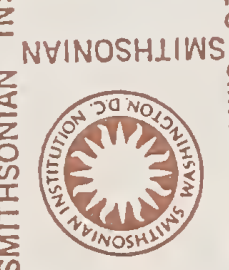

S 1 1 $\forall \forall 817$

$\frac{m}{\infty}$
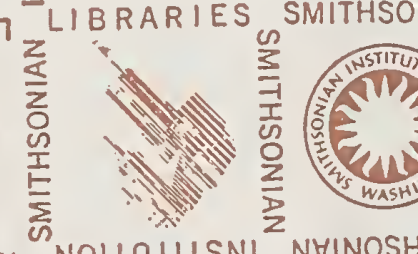

央
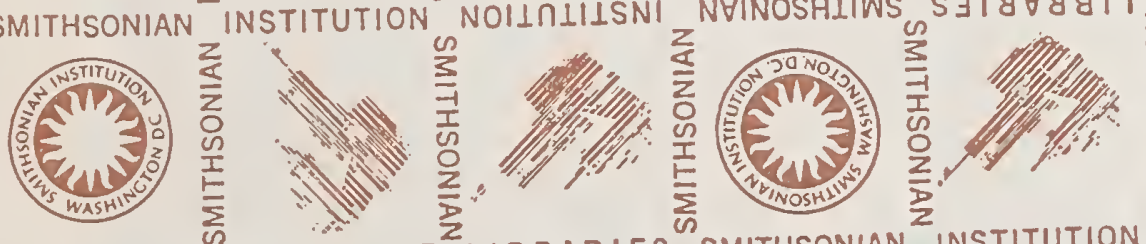

NOIINIIISNI

NHINOSH

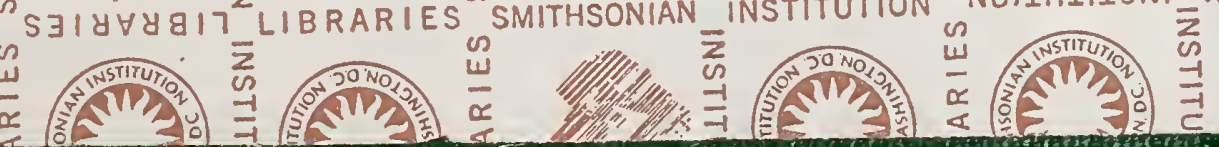


SMITHSONIAN INSTITUTION LIBRARIES

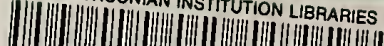

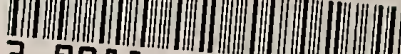

3908800307605

Thm Trerifo5. T29 2905

Teneriffe lace work. 